\title{
Spatial imprints of plate tectonics on extant richness of terrestrial vertebrates
}

\author{
Descombes Patrice ${ }^{1,2,{ }^{*}}$, Leprieur Fabien ${ }^{3}$, Albouy Camille ${ }^{1,2}$, Heine Christian ${ }^{4}$, Pellissier Loïc ${ }^{1,2}$
}

${ }^{1}$ Landscape Ecology; Institute of Terrestrial Ecosystems; ETH Zürich CH-8092 Zürich, Switzerland

2 Swiss Federal Research Institute WSL; CH-8903 Birmensdorf, Switzerland

${ }^{3}$ UMR MARBEC; (CNRS, IFREMER, IRD, UM); Université de Montpellier; Place Eugène Bataillon 34095 Montpellier ,France

${ }^{4}$ EarthByte Group; The University of Sydney; Sydney NSW ,Australia

* Corresponding author : Patrice Descombes, email address : patrice.descombes@wsl.ch

\begin{abstract}
:
Aim

In interaction with past climate changes, it is likely that plate tectonics contributed to the shaping of current global species diversity, but so far this has not been statistically quantified at the global level. Here, we tested whether plate tectonics since the breakup of Gondwana left an imprint on current patterns of species richness of amphibians, birds and mammals.
\end{abstract}

Location

Global.

Methods

We reconstructed the absolute positions of continental plates since the Early Cretaceous and used this information to derive variables of latitudinal shifts and potential exchanges among landmasses that could have modulated species richness. Using a multi-model inference approach combining both contemporary and historical variables, we quantified the relative importance of variables related to plate tectonics in explaining the spatial variation of the richness of amphibians, birds and mammals. Next, we employed a moving window approach to test whether plate tectonics left a more marked imprint in specific regions.

Results

Plate tectonics left an imprint on current patterns of vertebrate species richness in geologically singular regions, especially in the Indo-Australian Archipelago and the region comprising eastern Africa and Madagascar. For birds and mammals, but not amphibians, we found a marked contrast in species richness across Australia and Southeast Asia and eastern Africa and Madagascar associated with plate tectonics. Moreover, the relationship between species richness and plate tectonics varied across 
taxonomic orders for birds and mammals.

\section{Main conclusions}

While no general imprint of plate tectonics was detected at the global scale, our regional analysis highlighted a substantial role of geodynamics in shaping current patterns of vertebrate species richness in Southeast Asia and Madagascar. Future studies should integrate the full range of processes associated with plate tectonics, including orogeny, not considered here.

Keywords: amphibian, bird, continental drift, diversity, Indo-Pacific, Madagascar, mammal, plate tectonics, Southeast Asia, Wallace line 


\section{INTRODUCTION}

Contemporary environmental conditions, such as available energy (Currie, 1991; Kerr \& Packer, 1997; Rodríguez et al., 2005), net primary productivity (Currie, 1991) or habitat heterogeneity (Kerr \& Packer, 1997), may constrain the number of species coexisting in assemblages (Currie, 1991). Yet, different richness limits among ecologically similar regions suggest a possible legacy of historical contingences (Qian \& Ricklefs, 2000). For instance, North America and north-eastern Asia, two regions presenting similar temperate environments, display marked differences in plant species diversity (Qian \& Ricklefs, 1999, 2000). Historical events, such as cycles of climatic fluctuations during the Quaternary, are expected to have contributed to current species diversity patterns (Araújo et al., 2007; Leprieur et al., 2011; Sandel et al., 2011; Pellissier et al., 2014). However, few studies have investigated the role of ancient earth dynamics and assessed whether geological processes left an imprint on current species diversity (e.g. Jetz \& Fine, 2012; Kissling et al., 2012; BlachOvergaard et al., 2013; Belmaker \& Jetz, 2015).

Major geological events (e.g. the formation of mountain ranges or oceanic gateways through plate tectonics, island isolation by sea level changes) have influenced the distribution of clades and the composition of assemblages worldwide (e.g. Coblentz \& Riitters, 2004; Finarelli \& Badgley, 2010; Hoorn et al., 2010; Ali \& Aitchison, 2014; Gillepsie \& Roderick, 2014). For instance, the uplift of the Andean mountain range modified both the regional climate and the heterogeneity of the landscape, which favoured western Amazonian species diversification (Hoorn et al., 2010). Although orogenesis (i.e. mountain formation) and island isolation are processes commonly associated with speciation and diversity (Ron, 2000; Crochet et al., 2004; Ali \& Aitchison, 2014), plate tectonics, through continental breakup and dispersal, probably had the most profound effect on species geographical ranges. By isolating populations with hard geographic barriers such as deep oceanic gateways, this geological 
process favoured the formation of new lineages. In addition, the reunification of landmasses by continental collision, which occurred several times in the history of the earth (e.g. South North America, India - Asia, Australia - South Asia), also reorganized species assemblages through colonization and associated extinctions (Bossuyt \& Milinkovitch, 2001; Gillepsie \& Roderick, 2014). For instance, the northward motion of the Indian plate toward the Eurasian plate (between $90 \mathrm{Ma}$ and today) displaced vertebrate lineages, which showed high rates of diversification afterwards on the Asian continent (Bossuyt \& Milinkovitch, 2001). The continuous motion of continental plates throughout Earth's history led to progressively distinct continental assemblages (Holt et al., 2013) resulting from the combined influence of isolation and immigration processes (Gillepsie \& Roderick, 2014).

Plate tectonics may have shaped the diversity of species assemblages worldwide, in interaction with climatic stability and the potential for species exchanges among moving land masses (Markgraf et al., 1995; Leprieur et al., 2016). First, because of a relationship between climate and latitude (Hawkins \& Felizola Diniz-Filho, 2004), land masses that showed larger latitudinal shifts associated with plate tectonics probably experienced the strongest historical climatic changes. In turn, climatic instability is expected to be associated with a higher species extinction rate and lower species richness (Sandel et al., 2011; Pellissier et al., 2014). Second, smaller land masses that are disconnected over long periods of time are expected to have a lower immigration rate, which may result in comparatively lower richness in assemblages (Wiens \& Donoghue, 2004). Third, dispersal events across closely distributed land masses might fuel speciation and increase species richness in particular regions (Lavergne et al., 2013). While long-distance dispersal may occur sporadically between two land masses, limited gene flow prompts the emergence of disparate gene pools, which ultimately leads to speciation (Ali \& Aitchison, 2014). Climatic instability associated with 
latitudinal shifts, historical connectivity or opportunities for speciation across land masses may result in regional anomalies in species diversity.

Here, we investigated whether the legacy of plate tectonics is still detectable in the extant spatial distribution of species richness of amphibians, birds and mammals. Based on a global plate tectonics model covering the Early Cretaceous period to today, we quantified the latitudinal shift of land masses and the connectivity and potential for exchanges among proximate land masses during the last $140 \mathrm{Ma}$. Integrating plate tectonics into models of species diversity was predicted to provide a better understanding of the diversity of extant species assemblages. We expected that the relationship between plate tectonics and extant diversity would vary across regions because the dynamics of plate tectonics was more pronounced is some regions than others. In addition, relationships between species diversity and plate tectonics was predicted to depend on life-history characteristics varying strongly among taxonomic groups (Sandel et al., 2011).

\section{MATERIALS AND METHODS}

\section{Species richness data}

We used a global dataset of the distribution ranges of all known extant amphibian, bird and mammal species (Jenkins et al., 2013). Original richness maps were generated based on the polygons obtained from BirdLife International for birds (BirdLife International \& NatureServe 2015) and from the IUCN Red list for amphibians and terrestrial mammals (IUCN 2015), as in previous studies (e.g. Holt et al., 2013; Marin \& Hedges, 2016). From this database, and following Hurlbert \& Jetz (2007), we mapped the species richness of amphibians, birds and mammals, defined as the total number of species recorded in each grid cell, by transforming individual species shapefiles into equal area raster grids at a resolution 
of $1^{\circ}$ (i.e. 111.195 km; see Fig. S1 in Appendix S1). Marine species and Antarctica were not considered in the analyses.

\section{Plate motion history predictor variables}

We generated palaeogeographic reconstructions showing the area of exposed land surface in absolute palaeo-positions from the breakup of Gondwana in the Early Cretaceous (140 Ma) to the present in 1 Ma steps (see Fig. S2 in Appendix S1). We used the open source software GPlates (http://www.gplates.org; Boyden et al., 2011) in combination with a newly devised set of digital palaeoshoreline positions (Heine et al., 2015) and a global plate motion model (Müller et al., 2008) to generate gridded, individual palaeogeographic reconstructions for land surface area at a temporal resolution of 1 Ma based on geological observations (Smith et al., 1994). Local models of plate tectonics may provide a more detailed picture of the movement of land masses (e.g. Southeast Asia; Hall, 1996). The standardized model available at the global scale that we used in this study may thus underestimate local geological complexity, especially in the Southeast Asian region.

Based on reconstructed palaeogeographies, we computed three spatial metrics relevant for explaining species diversity. First, because of a relationship between climate and latitude (Hawkins \& Felizola Diniz-Filho, 2004), land masses that showed larger latitudinal shifts associated with plate tectonics probably experienced the strongest historical climatic changes. In turn, climatic instability is expected to be associated with a higher species extinction rate and lower species richness (Sandel et al., 2011; Pellissier et al., 2014). Thus, we computed the latitudinal shift of land masses since the Early Cretaceous for each terrestrial cell as the cumulative latitudinal distance crossed by a given land patch under plate motion (i.e. latitudinal shift history variable; Fig. 1a). A new terrestrial cell at time $t$ was assigned the 
value corresponding to the latitudinal distance to the closest cell at time $t-1$, and summed to the value of the closest cell at time $t-1$. Second, because smaller land masses that are disconnected over long periods of time are expected to have a lower immigration rate, which may result in comparatively lower richness in assemblages (Wiens \& Donoghue, 2004), we developed a variable representing the accumulated connectivity through time by computing the mean distance of a given cell to all cells connected by land through time using the "gdistance" library (van Etten, 2015) in R (R Development Core Team, www.R-project.org; see Fig. S3 in Appendix S1). Third, based on the hypothesis that potential dispersal among land masses fuels speciation, we quantified the potential for dispersal across disconnected land masses separated by sea barriers since the Early Cretaceous (i.e. land-bridges history variable; Fig. 1b). During each time slice of one million years, we defined the land masses separated by at least one cell of sea using an algorithm of cluster splits implemented in the "dbscan" function in the "fpc" library (Hennig, 2015) in R. For each cell, we quantified the number of surrounding cells from disconnected land masses below a dispersal distance $d$ (Fig. 1b). A larger number of possible donor cells is assumed to increase the chance of long distance dispersal across a sea barrier. To accommodate the movement of the continents, the cell values at time $t$ were transferred to the closest cell value at time $t+1$. Areas with high geological complexity for an extended period are expected to have the highest potential for allopatric speciation to shape species richness across barriers. This computation was replicated for different dispersal distance $d$ (in degrees: 5, 10, 15, 20, 25 and 30). The variable of land-bridges history was computed as the sum of the different outputs.

\section{Additional predictor variables}

It is widely recognized that contemporary topo-climatic variables modulate the current global distribution of species richness (e.g. Currie, 1991; Kerr \& Packer, 1997; Rodríguez et al., 2005). We considered a set of three contemporary variables by using an equal area grid at a 
resolution of $1^{\circ}$ : annual net primary productivity [g C/m²/year] (Imhoff et al., 2004), potential evapo-transpiration [mm/month] (Trabucco \& Zomer, 2009) and landscape heterogeneity (see Fig. S4 in Appendix S1). Regions with higher topographic roughness have,

in general, greater habitat diversity and are associated with higher species richness (Rahbek, 1995; Kerr \& Packer, 1997). We calculated the landscape heterogeneity as the standard deviation of elevation values in area grid cells of $1^{\circ}$ from a $0.16^{\circ}$ resolution digital elevation model (http://www.worldclim.org/).

More recent historical events, such as Quaternary climate fluctuations, might have influenced large-scale richness patterns (Araújo et al., 2007; Sandel et al., 2011). We considered an additional variable related to Late Quaternary climate-change, the velocity of climate change since the Last Glacial Maximum (Sandel et al., 2011), using a grid with a resolution of $1^{\circ}$. Climate velocity [m/year] can be interpreted as an indicator of the distance that species had to move each year to track suitable conditions during the Quaternary climate fluctuations (see Fig. S4 in Appendix S1).

\section{Global analyses}

We related global species richness to historical (latitudinal shift history, land-bridges history and Late Quaternary climate-change velocity) and contemporary (net primary productivity, potential evapo-transpiration and landscape heterogeneity) variables by using an ordinary least squares regression (OLS) model and including all predictor variables and quadratic terms to account for non-linear relationships. The proportion of the variation in species richness explained by the OLS models was quantified with the coefficient of determination $\left(R^{2}\right)$. We also compared the OLS parameter estimates to those obtained using a simultaneous autoregressive (SAR) model (Kissling et al., 2008) to account for spatial autocorrelation in 
the residuals that may bias the estimation of parameters (Dormann et al., 2007). The SAR model incorporates a spatially dependent error term to adjust for spatial autocorrelation. We used a spatial weight matrix with neighbourhoods defined as all cells within $200 \mathrm{~km}$ of the focal cell and applied a Moran's I global test to determine whether autocorrelation persisted in the SAR models. Since collinearity can bias parameter estimation in regression-type models, we calculated a variance inflation factor (VIF; Quinn \& Keough 2002) for the predictors using the "vifstep" function in the "usdm" package (Naimi, 2015). An ideal VIF has a value of one, while VIF values higher than three are indicative of collinearity issues (Quinn \& Keough, 2002; Zuur et al., 2010; Mundry, 2014). After removing the variable of connectivity through time (see Fig. S3 in Appendix S1), which was correlated with latitudinal shift (Spearman's correlation: $r=0.403$ ), collinearity among variables was low (VIF values: net primary productivity $=1.298$, potential evapo-transpiration $=1.928$, landscape heterogeneity $=1.119$, Late Quaternary climate-change velocity $=1.279$, latitudinal shift history $=1.226$, land-bridges history $=1.337$ ).

Based on the full OLS and SAR models, we quantified the support for each competing model, including all possible contemporary and historical variables, using the Akaike information criterion (AIC, see Burnham \& Anderson, 2002). The probability that a specific model was the best was estimated with the Akaike weight $(w)$ for each subset model (Kissling et al., 2008). The relative importance of each predictor variable was assessed by summing Akaike weight values $\left(W_{A I C}\right)$ of each subset model including the predictor (Burnham \& Anderson, 2002; Diniz-Filho et al., 2008). Summed Akaike weights range from 0 to 1 and provide a ranking of variables in terms of information content (Sandel et al., 2011). The selection of the minimum adequate model (MAM; i.e. the best model) was based on the lowest AIC value. All these analyses were performed using the package "MuMIn" (Barton, 2016) in R. We used a variance partitioning analysis (Borcard et al., 1992) to decompose the proportion of variation 
in species richness explained by the full OLS models $\left(R^{2}\right)$ into three sources of variation by means of partial regressions (Legendre, 2012): (i) variation due to the independent effect of plate tectonics variables, $(\mathrm{ii})$ variation due to the independent effect of contemporary variables (including Late Quaternary climate-change velocity), and (iii) variation due to the combined effect of historical and contemporary variables. We investigated the three taxonomic classes (birds, mammals and amphibians) as well as taxonomic orders including at least eight species per $1^{\circ}$ square at the global scale.

\section{Regional analyses}

We investigated the regional and independent influence of latitudinal shift and land-bridges history on species richness in square focal moving windows of various sizes (range of width used: from $40^{\circ}$ to $80^{\circ}$ by $2^{\circ}$ ) using a variance partitioning analysis (same method as that used at the global scale). The calculation was limited to cells situated between $-60^{\circ}$ and $60^{\circ}$ latitude and to focal regions including at least ten cells. We mapped the regional effect by averaging the results from multiple sizes of focal windows. Then, we related species richness to historical and contemporary variables in regions of interest (square regions $60^{\circ}$ x $60^{\circ}$; see Fig. S5 in Appendix S1) using OLS and SAR models with the same method as that used at the global scale. We quantified the relative importance of historical versus contemporary variables in explaining species richness variation in the selected regions, using a variance partitioning analysis for the three classes (birds, mammals and amphibians) and for different taxonomic orders including at least eight species per $1^{\circ}$ square in the selected region. 


\section{RESULTS}

\section{Global model}

Plate motion history received large support in OLS models mixing historical and contemporary variables (OLS models: $W_{A I C}=1, P<0.05$; see Table S1 in Appendix S1). However, when spatial autocorrelation was accounted for, the variables related to plate tectonics were no longer statistically significant (SAR models: $W_{A I C}<0.64, P>0.05$; see Table S1 in Appendix S1), indicating that the effect of geological history was spatially aggregated. When the explained variance of species richness (Amphibians: $R^{2}=0.68$, birds: $R^{2}=0.75$, mammals: $R^{2}=0.74$; see Table $\mathrm{S} 1$ in Appendix S1) was partitioned among contemporary and historical variables, plate motion history displayed a low independent contribution (amphibians: 1.03\%, birds: 2.24\%, mammals: $3.74 \%$; see Table S2 in Appendix S1) compared to contemporary variables (amphibians: 62.49\%, birds: $63.45 \%$, mammals: 60.46\%; see Table S2 in Appendix S1). At the level of taxonomic order, plate motion history displayed a higher independent contribution, especially in three mammalian orders (Afrosoricidae: 46.93\%, Dasyuromorphia: 29.87\%, Diprotodontia: 22.65\%; see Table S2 and Fig. S6 in Appendix S1), than contemporary variables (Afrosoricidae: 4.63\%, Dasyuromorphia: 6.56\%, Diprotodontia: 3.06\%; see Table S2 and Fig. S6 in Appendix S1). The independent contribution of plate motion history was generally higher than that of Late Quaternary climate-change velocity in all taxonomic groups except for Caudata, Procellariformes and Cuculiformes (see Table S2 and Fig. S6 in Appendix S1).

\section{Regional models}

The moving windows showed a large contribution of plate motion history in two main regions: the Indo-Australian Archipelago (maximum values; amphibians: 13.51\%, birds: 
19.19\%, mammals: 29.36\%; Fig. 2) and eastern Africa and Madagascar (amphibians: 6.21\%, birds: $37.63 \%$, mammals: $34.14 \%$; Fig. 2).

In the Indo-Australian Archipelago, plate motion history received overall large support in OLS and SAR models mixing historical and contemporary variables (OLS and SAR models: $W_{\text {AIC }}>0.91, P<0.05$; Table 1). When the explained variance of species richness (amphibians: $R^{2}=0.51$, birds: $R^{2}=0.75$, mammals: $R^{2}=0.77$; Table 1) was partitioned, plate motion history displayed a large independent contribution (amphibians: 8.93\%, birds: 14.39\%, mammals: 24.07\%; see Table S3 in Appendix S1) that did not overlap with contemporary factors (amphibians: $13.95 \%$, birds: $15.35 \%$, mammals: $11.36 \%$; see Table S3 in Appendix S1). At the level of taxonomic order, plate tectonics variables displayed a large independent explained variance in several bird and mammal orders (e.g. Piciformes: 44.06\%, Psittaciformes: 31.23\%, Carnivora: 39.15\%, Primates: 39.04\%; Fig. 3a and see Table S3 in Appendix S1) compared to contemporary variables (e.g. Piciformes: 6.13\%, Psittaciformes: 17.74\%, Carnivora: 1.71\%, Primates: 5.94\%; Fig. 3a and see Table S3 in Appendix S1).

In eastern Africa and Madagascar, plate motion history received large support in OLS models mixing historical and contemporary variables (OLS models: $W_{A I C}=1, P<0.05$; Table 2), but only with amphibians in the SAR models $\left(W_{A I C}>0.86, P<0.05\right.$; Table 2$)$. When the explained variance was partitioned among contemporary and historical variables, the plate motion history explained a large portion of the variance (amphibians: $6.13 \%$, birds: $29.81 \%$, mammals: 26.25\%; see Table S4 in Appendix S1) that did not overlap with contemporary factors (amphibians: 32.28\%, birds: 27.76\%, mammals: 27.14\%; see Table S4 in Appendix S1). At the level of taxonomic order, plate tectonics variables displayed a large independent explained variance in several amphibian, bird and mammal orders (e.g. Gymnophiona: 15.35\%, Accipitroformes: 33.65\%, Bucerotiformes: 28.90\%, Carnivora: 59.73\%, Afrosoricida: 50.13\%; Fig. 3b and see Table S4 in Appendix S1) compared to contemporary 
variables (e.g. Gymnophiona: 4.34\%, Accipitroformes: 28.99\%, Bucerotiformes: $17.92 \%$, Carnivora: 8.20\%, Afrosoricida: 4.11\%; Fig. 3b and see Table S4 in Appendix S1).

\section{DISCUSSION}

By reconstructing the absolute continental plate position since the Early Cretaceous, we showed that plate tectonics left an imprint on current patterns of vertebrate species richness. The relationship between plate movements and species richness was only partially supported at the global scale, and attenuated once spatial autocorrelation was accounted for in the statistical models. This, together with the mobile window analyses, indicated that the relationship between plate tectonics and vertebrate species richness was mainly driven by two regions: the Indo-Australian Archipelago (IAA) and the region including eastern Africa and Madagascar.

The imprint of the plate tectonics on vertebrate species richness was particularly strong in the Indo-Australian Archipelago (Fig. 2). Large discontinuities in the taxonomic composition of species assemblages have been observed across the Wallace line (Wallace, 1860, Holt et al., 2013), which highlights the contact area of the Asian and Australian plates (Hall, 2001). The marked spatial gradient of species richness between Borneo and Sulawesi was associated with geological history and, more particularly, to the variable related to latitudinal shift. After starting its northward motion towards Asia (around 50 - 45 Ma; see Fig. S2 in Appendix S1), Australia crossed through the temperate, subtropical and tropical belts and underwent strong climate fluctuations (e.g. Crisp et al., 2004; Hill, 1994, 2004; Markgraf et al., 1995) that were particularly marked during the Neogene and Quaternary periods (e.g. Kershaw et al., 1994; Sniderman et al., 2007). Biological evidence (e.g. Morley, 1998; Crisp et al., 2004; Byrne et al., 2011) and vegetation reconstructions (Herold et al., 2011) suggest that climatic 
modifications have altered biome distribution and, in turn, might have led to shifts in species diversity. Nevertheless, the variable related to latitudinal shift was correlated with connectivity of land masses through time in the Indo-Australian Archipelago (Spearman's correlation: $r=0.87$ ). Therefore, the lower richness in Australia is also associated with lower opportunities for immigration (Lohman et al., 2011).

We observed a significant imprint of plate tectonics on species richness patterns in eastern Africa and Madagascar. The early separation of Madagascar, in combination with asymmetrical exchanges with the mainland of Africa, likely maintained a comparatively lower diversity on this island (Ali \& Huber, 2010). Madagascar separated from Africa around 183 - $158 \mathrm{Ma}$, from Antarctica around $125-110 \mathrm{Ma}$ and from India around 96 - $65 \mathrm{Ma}$ (Ali \& Aitchison, 2008). The species in Madagascar originated either from vicariance after the separation of the island or from oversea dispersal events from Africa (Yoder \& Nowak, 2006; Bacon et al., 2016) or from the subcontinent of India (Crottini et al., 2012). Moreover, it is expected that unfavourable sea currents in the Miocene limited the colonization of the island from Africa (Ali \& Huber, 2010). As a consequence, the lower species richness in Madagascar is associated with a long history of isolation.

We found no significant imprint of plate tectonics on species richness in North and South America. Overall, North and South America retained stable latitudes and large continental landmasses (with low geological complexity in our plate motion reconstruction not accounting for palaeo-elevation), and therefore no major contrasts were observed in the variables derived from plate tectonics in and between South and North America (Fig. 1). While differences in species composition as a result of long term continental isolation have been reported (Simpson, 1980), the connection between North and South America by the Isthmus of Panama allowed species exchanges in both directions (Webb, 2006; Woodburne, 2010; Bacon et al., 2015; Montes et al., 2015; O’Dea et al., 2016), attenuating any previous 
difference in species diversity and composition. In contrast, the Indian plate underwent substantial latitudinal drift during its northward motion towards the Eurasian plate (between $90 \mathrm{Ma}$ and today), which was visible in the variables of plate motion history (Fig. 1a and see Fig. S2 in Appendix S1). Yet, the small independent effect of plate tectonics on species richness in India results from a confounding effect with contemporary variables: the lower species richness in India is statistically associated with both lower contemporary productivity and a singular geological history (Bossuyt \& Milinkovitch, 2001; Gillepsie \& Roderick, 2014).

The strength of the relationship between species richness and plate tectonics varied across taxonomic groups at the global and regional scales (Fig. 3 and see Fig. S6 in Appendix S1). These results were associated with the aforementioned contrasts in the spatial distribution of the taxonomic groups: Afrosoricidae are more diverse in Madagascar than in eastern Africa (Fig. 3b and see Fig. S6 in Appendix S1); Piciformes are absent from Madagascar, Australia and New-Guinea, but are very diverse in Southeast Asia and eastern Africa (Fig. 3);

Carnivora are poorly diverse in Madagascar and are absent from Australia and New-Guinea, but are very diverse in eastern Africa and Southeast Asia (Fig. 3 and see Fig. S6 in Appendix S1); Dasyuromorphia and Diprotodontia are only found in Australia and New-Guinea, but are absent from Southeast Asia (Fig. 3a and see Fig. S6 in Appendix S1). Most flying species, such as birds and bats, also displayed a lower association with variables related to plate tectonics, especially in the Indo-Australian Archipelago (Fig. 3a). In contrast, most orders of mammals (e.g. Carnivora, Diprotodontia, Primates), and low distance dispersing birds (e.g. Psittaciformes) showed a strong association with variables related to plate tectonics in the Indo-Australian Archipelago (Fig. 3a). Even if the Wallace biogeographic barrier has been shown to be weaker for plants (Van Welzen et al., 2011) and some insects (Beck et al., 2006) than for vertebrates, many species in our analyses persist on either side of the barrier due to 
dispersal limitations (Van Welzen et al., 2011; Bacon et al., 2013), as reflected in our modelled relationships.

The variables considered in our study represent a coarse quantification of the net effect of plate tectonics on species assemblages, and many processes that are the result of plate tectonics, such as climate change (Raymo \& Ruddiman, 1992; Ramstein et al., 1997) and orogeny (Antonelli et al., 2009; Hoorn et al., 2013), were not accounted for. Orogeny can drive global climate change through its influence on the carbon cycle (Ruddiman, 1997) as well as its strong effect on regional modifications of topography-related climate dynamics (Sepulchre et al., 2006, Poulsen et al., 2010), which in turn have been shown to influence macro-evolutionary processes (Antonelli et al., 2009; Hoorn et al., 2013; Favre et al. 2014). In addition, the variable quantifying latitudinal shift is a coarse estimation of climatic changes. Future studies should couple plate tectonics with palaeoclimate models (Sellwood \& Valdes, 2006; Fluteau et al., 2007; Herold et al., 2011; Chaboureau et al., 2014), for instance to reconstruct temperature and precipitation, which fluctuated in Australia during the last million years (e.g. Hill, 1994, 2004). Finally, the resolution of the global tectonic model was relatively coarse and did not include many archipelagos, which could in turn have conferred a stronger global signal (Condamine et al., 2016). Overall, future developments in the field of palaeogeography are needed to provide palaeogeographic reconstructions with a finer spatial and temporal resolution in order to match current biodiversity data.

To conclude, the aim of the present study was to quantify whether plate tectonics left an imprint on current patterns of vertebrate species richness. In addition to confirming the high turnover of clades over a short geographical distance (Wallace, 1860; Mayr, 1944; Mayr \& Diamond, 2001), our results suggest that plate tectonics is associated with current patterns of vertebrate species richness in singular geological regions, such as the Indo-Australian Archipelago (IAA) and the region comprising eastern Africa and Madagascar. While the link 
between plate tectonics and species diversity was already discussed (Briggs, 1987), especially in those regions (e.g. Wilson \& Rosen, 1998; Keith et al., 2013), our study paves the way toward a better quantification of the role of ancient geological events in shaping extant biodiversity patterns (Leprieur et al., 2016).

\section{ACKNOWLEDGEMENTS}

We thank the reviewers and Melissa Dawes who provided suggestions to improve the manuscript. This study was financed by the FNS project REEFISH n³10030E-164294.

\section{REFERENCES}

Ali J.R. \& Aitchison J.C. (2008) Gondwana to Asia: Plate tectonics, paleogeography and the biological connectivity of the Indian sub-continent from the Middle Jurassic through latest Eocene (166-35 Ma). Earth-Science Reviews, 88, 145-166.

Ali J.R. \& Aitchison J.C. (2014) Exploring the combined role of eustasy and oceanic island thermal subsidence in shaping biodiversity on the Galápagos. Journal of Biogeography, 41, 1227-1241.

Ali J.R. \& Huber M. (2010) Mammalian biodiversity on Madagascar controlled by ocean currents. Nature, 463, 653-6.

Antonelli A., Nylander J.A.A., Persson C., \& Sanmart1 I. (2009) Tracing the impact of the Andean uplift on Neotropical plant evolution. 106, 9749-9754.

Araújo M.B., Nogués-Bravo D., Diniz-Filho J.A.F., Haywood A.M., Valdes P.J., \& Rahbek C. (2007) Quaternary climate changes explain diversity among reptiles and amphibians. Ecography, 31, 8-15.

Bacon C.D., Michonneau F., Henderson A.J., McKenna M.J., Milroy A.M., \& Simmons M.P. (2013) Geographic and taxonomic disparities in species diversity: dispersal and diversification rates across Wallace's line. Evolution, 67, 2058-2071.

Bacon C.D., Silvestro D., Jaramillo C., Smith B.T., Chakrabarty P., \& Antonelli A. (2015) Biological evidence supports an early and complex emergence of the Isthmus of Panama. Proceedings of the National Academy of Sciences USA, 112, 6110-6115.

Bacon C.D., Simmons M.P., Archer R.H., Zhao L.C., \& Andriantiana J. (2016) Biogeography of the Malagasy Celastraceae: Multiple independent origins followed by widespread dispersal of genera from Madagascar. Molecular Phylogenetics and Evolution, 94, 365382.

Baker A.J., Huynen L.J., Haddrath O., Millar C.D., \& Lambert D.M. (2005) Reconstructing 
the tempo and mode of evolution in an extinct clade of birds with ancient DNA: the giant moas of New Zealand. Proceedings of the National Academy of Sciences USA, 102, $8257-8262$.

Barton K. (2016) MuMIn: Multi-Model Inference. R package version 1.15.6. https://CRAN.R-project.org/package=MuMIn.

Beck J., Kitching I.J., \& Linsenmair K.E. (2006) Wallace's line revisited : has vicariance or dispersal shaped the distribution of Malesian hawkmoths (Lepidoptera: Sphingidae)? Biological Journal of the Linnean Society, 89, 455-468.

Belmaker J. \& Jetz W. (2015) Relative roles of ecological and energetic constraints, diversification rates and region history on global species richness gradients. Ecology Letters, 18, 563-571.

BirdLife International \& NatureServe (2015) Bird species distribution maps of the world. BirdLife International/NatureServe, Cambridge, UK/Arlington, USA.

Blach-Overgaard A., Kissling W.D., Dransfield J., Balslev H., \& Svenning J.C. (2013) Multimillion-year climatic effects on palm species diversity in Africa. Ecology, 94, 2426-2435.

Borcard D., Legendre P., \& Drapeau P. (1992) Partialling out the spatial component of ecological variation. Ecology, 73, 1045-1055.

Bossuyt F. \& Milinkovitch M.C. (2001) Amphibians as indicators of Early Tertiary "Out-ofIndia" dispersal of vertebrates. Science, 292, 93-95.

Boyden J.A., Müller R.D., Gurnis M., Torsvik T.H., Clark J.A., Turner M., Ivey-Law H., Watson R.J., \& Cannon J.S. (2011) Next-generation plate-tectonic reconstructions using GPlates. Geoinformatics: cyberinfrastructure for the solid earth sciences (ed. by G.R. Keller and C. Baru), pp. 95-114. Cambridge University Press.

Briggs J.C. (1987) Biogeography and plate tectonics (Vol. 10). Elsevier, Amsterdam.

Burnham K.P. \& Anderson D.R. (2002) Model Selection and Multimodel Inference: A Practical Information-Theoretic Approach. Springer-Verlag, Berlin.

Byrne M., Steane D. a., Joseph L., Yeates D.K., Jordan G.J., Crayn D., Aplin K., Cantrill D.J., Cook L.G., Crisp M.D., Keogh J.S., Melville J., Moritz C., Porch N., Sniderman J.M.K., Sunnucks P., \& Weston P.H. (2011) Decline of a biome: evolution, contraction, fragmentation, extinction and invasion of the Australian mesic zone biota. Journal of Biogeography, 38, 1635-1656.

Chaboureau A.-C., Sepulchre P., Donnadieu Y., \& Franc A. (2014) Tectonic-driven climate change and the diversification of angiosperms. Proceedings of the National Academy of Sciences USA, 111, 14066-14070.

Coblentz D.D. \& Riitters K.H. (2004) Topographic controls on the regional-scale biodiversity of the south-western USA. Journal of Biogeography, 31, 1125-1138.

Condamine F.L., Leslie A.B., \& Antonelli A. (2016) Ancient islands acted as refugia and pumps for conifer diversity. Cladistics, doi: 10.1111/cla.12155.

Crisp M., Cook L., \& Steane D. (2004) Radiation of the Australian flora: what can comparisons of molecular phylogenies across multiple taxa tell us about the evolution of diversity in present-day communities? Philosophical transactions of the Royal Society of London. Series B, Biological sciences, 359, 1551-71.

Crochet P., Chaline O., Surget-Groba Y., Debain C., \& Cheylan M. (2004) Speciation in 
mountains: phylogeography and phylogeny of the rock lizards genus Iberolacerta (Reptilia: Lacertidae). Molecular phylogenetics and evolution, 30, 860-866.

Crottini A., Madsen O., Poux C., Strauss A., Vieites D.R., \& Vences M. (2012) Vertebrate time-tree elucidates the biogeographic pattern of a major biotic change around the K-T boundary in Madagascar. Proceedings of the National Academy of Sciences USA, 109, 5358-5363.

Currie D.J. (1991) Energy and large-scale patterns of animal- and plant-species richness. The American Naturalist, 137, 27-49.

Diniz-Filho J.A.F., Rangel T.F.L.V.B., \& Bini L.M. (2008) Model selection and information theory in geographical ecology. Global Ecology and Biogeography, 17, 479-488.

Dormann C.F., McPherson J.M., Araújo M.B., Bivand R., Bolliger J., Carl G., Davies R.G., Hirzel A., Jetz W., Kissling W.D., Kühn I., Ohlemüller R., Peres-Neto P.R., Reineking B., Schröder B., Schurr F.M., \& Wilson R. (2007) Methods to account for spatial autocorrelation in the analysis of species distributional data: a review. Ecography, 30, 609-628.

van Etten J. (2015) gdistance: Distances and Routes on Geographical Grids. R package version 1.1-9. https://CRAN.R-project.org/package=gdistance.

Feder M.E. \& Burggren W.W. (1992) Environmental physiology of the amphibians. University of Chicago Press,

Finarelli J.A. \& Badgley C. (2010) Diversity dynamics of Miocene mammals in relation to the history of tectonism and climate. Proceedings of The Royal Society B, 277, 2721-2726.

Fluteau F., Ramstein G., Besse J., Guiraud R., \& Masse J.P. (2007) Impacts of palaeogeography and sea level changes on Mid-Cretaceous climate. Palaeogeography, Palaeoclimatology, Palaeoecology, 247, 357-381.

Gillepsie R.G. \& Roderick G.K. (2014) Geology and climate drive diversification. Nature, 509, 297-298.

Hall R. (1996) Reconstructing Cenozoic SE Asia. Geological Society, London, Special Publications, 106, 153-184.

Hall R. (2001) Cenozoic reconstructions of SE Asia and the SW Pacific: changing patterns of land and sea. Faunal and floral migrations and evolution in SE Asia-Australasia. pp. $35-56$.

Hawkins B.A. \& Felizola Diniz-Filho J.A. (2004) "Latitude" and geographic patterns in species richness. Ecography, 27, 268-272.

Heine C., Yeo L.G., \& Müller R.D. (2015) Evaluating global paleoshoreline models for the Cretaceous and Cenozoic. Australian Journal of Earth Sciences, 62, 275-287.

Hennig C. (2015) fpc: Flexible Procedures for Clustering. R package version 2.1-10. https://CRAN.R-project.org/package=fpc.

Herold N., Huber M., Greenwood D.R., Müller R.D., \& Seton M. (2011) Early to Middle Miocene monsoon climate in Australia. Geology, 39, 3-6.

Hill R.S. (1994) History of the Australian vegetation: Cretaceous to Recent. Cambridge University Press,

Hill R.S. (2004) Origins of the southeastern Australian vegetation. Philosophical Transactions of the Royal Society of London B: Biological Sciences, 359, 1537-1549.

Holt B.G., Lessard J.-P., Borregaard M.K., Fritz S. a, Araújo M.B., Dimitrov D., Fabre P.-H., 
Graham C.H., Graves G.R., Jønsson K. a, Nogués-Bravo D., Wang Z., Whittaker R.J., Fjeldså J., \& Rahbek C. (2013) An update of Wallace's zoogeographic regions of the world. Science, 339, 74-8.

Hoorn C., Mosbrugger V., Mulch A., \& Antonelli A. (2013) Biodiversity from mountain building. Nature Geoscience, 6, 154.

Hoorn C., Wesselingh F.P., ter Steege H., Bermudez M. a, Mora A., Sevink J., Sanmartín I., Sanchez-Meseguer A., Anderson C.L., Figueiredo J.P., Jaramillo C., Riff D., Negri F.R., Hooghiemstra H., Lundberg J., Stadler T., Särkinen T., \& Antonelli A. (2010) Amazonia through time: Andean uplift, climate change, landscape evolution, and biodiversity. Science, 330, 927-931.

Hurlbert A.H. \& Jetz W. (2007) Species richness, hotspots, and the scale dependence of range maps in ecology and conservation. Proceedings of the National Academy of Sciences USA, 104, 13384-13389.

Imhoff M.L., Bounoua L., Ricketts T., Loucks C., Harriss R., \& Lawrence W.T. (2004) Available at: http://sedac.ciesin.columbia.edu.

Jenkins C.N., Pimm S.L., \& Joppa L.N. (2013) Global patterns of terrestrial vertebrate diversity and conservation. Proceedings of the National Academy of Sciences USA, 110, E2602-E2610.

Jetz W. \& Fine P.V. a (2012) Global gradients in vertebrate diversity predicted by historical area-productivity dynamics and contemporary environment. PLoS Biology, 10, e1001292.

Keith S.A., Baird A.H., Hughes T.P., Madin J.S., \& Connolly S.R. (2013) Faunal breaks and species composition of Indo-Pacific corals: the role of plate tectonics, environment and habitat distribution. Proceedings of the Royal Society of London B: Biological Sciences, 280, 20130818.

Kerr J.T. \& Packer L. (1997) Habitat heterogeneity as a determinant of mammal species richnesss in high-energy regions. Nature, 385, 252-254.

Kershaw A.P., Martin H.A., \& McEwen Mason J.R.C. (1994) The Neogene: a period of transition. History of the Australian vegetation: Cretaceous to Recent pp. 299-327. Cambridge University Press, Cambridge.

Kissling W.D., Eiserhardt W.L., Baker W.J., Borchsenius F., Couvreur T.L.P., Balslev H., \& Svenning J.-C. (2012) Cenozoic imprints on the phylogenetic structure of palm species assemblages worldwide. Proceedings of the National Academy of Sciences USA, 109, 7379-7384.

Kissling W.D., Field R., \& Böhning-Gaese K. (2008) Spatial patterns of woody plant and bird diversity: functional relationships or environmental effects? Global Ecology and Biogeography, 17, 327-339.

Lavergne S., Hampe A., \& Arroyo J. (2013) In and out of Africa: how did the Strait of Gibraltar affect plant species migration and local diversification? Journal of Biogeography, 40, 24-36.

Legendre L. (2012) Numerical Ecology. Elsevier, Amsterdam.

Leprieur F., Descombes P., Gaboriau T., Cowman P.F., Parravicini V., Kulbicki M., Melián C.J., de Santana C.N., Heine C., Mouillot D., Bellwood D.R., \& Pellissier L. (2016) Plate tectonics drive tropical reef biodiversity dynamics. Nature Communications, 7 , 11461, doi:10.1038/ncomms11461. 
Leprieur F., Tedesco P.A., Hugueny B., Beauchard O., Dürr H.H., Brosse S., \& Oberdorff T. (2011) Partitioning global patterns of freshwater fish beta diversity reveals contrasting signatures of past climate changes. Ecology Letters, 14, 325-334.

Lohman D.J., de Bruyn M., Page T., von Rintelen K., Hall R., Ng P.K.L., Shih H.-T., Carvalho G.R., \& von Rintelen T. (2011) Biogeography of the Indo-Australian Archipelago. Annual Review of Ecology, Evolution, and Systematics, 42, 205-226.

Marin J. \& Hedges S.B. (2016) Time best explains global variation in species richness of amphibians, birds and mammals. Journal of Biogeography, 43, 1069-1079.

Markgraf V., McGlone M., \& Hope G. (1995) Neogene paleoenvironmental and paleoclimatic change in southern temperate ecosystems - a southern perspective. Trends in Ecology \& Evolution, 10, 143-147.

Mayr E. (1944) Wallace's line in the light of recent zoogeographic studies. The Quarterly Review of Biology, 19, 1-14.

Mayr E. \& Diamond J.M. (2001) The birds of northern Melanesia. Oxford University Press, New York.

Montes C., Cardona A., Jaramillo C., Pardo A., Silva J.C., Valencia V., Ayala C., PérezAngel L.C., Rodriguez-Parra L.A., Ramirez V., Niño H. (2015) Middle Miocene closure of the Central American seaway. Science, 348, 226-229.

Morley R.J. (1998) Palynological evidence for Tertiary plant dispersals in the SE Asian region in relation to plate tectonics and climate. Biogeography and geological evolution of SE Asia. pp. 211-234.

Müller R.D., Sdrolias M., Gaina C., Steinberger B., \& Heine C. (2008) Long-term sea-level fluctuations driven by ocean basin dynamics. Science, 319, 1357-1362.

Mundry R. (2014) Statistical issues and assumptions of phylogenetic generalized least squares. Modern phylogenetic comparative methods and their application in evolutionary biology (ed. by L.Z. Garamszegi), pp. 131-153. Springer-Verlag Berlin, Heidelberg.

Naimi B. (2015) Uncertainty Analysis for Species Distribution Models. R package version 1.1-15. https://cran.r-project.org/web/packages/usdm/index.

O'Dea A., Lessios H.A., Coates A.G., Eytan R.I., Restrepo-Moreno S.A., Cione A.L., Collins L.S., de Queiroz A., Farris D.W., Norris R.D., Stallard R.F., Woodburne M.O., Aguilera O., Aubry M.-P., Berggren W.A., Budd A.F., Cozzuol M.A., Coppard S.E., Duque-Caro H., Finnegan S., et al. (2016) Formation of the Isthmus of Panama. Science Advances, 2 , e1600883-e1600883.

Pellissier L., Leprieur F., Parravicini V., Cowman P.F., Kulbicki M., Litsios G., Olsen S.M., Wisz M.S., Bellwood D.R., \& Mouillot D. (2014) Quaternary coral reef refugia preserved fish diversity. Science, 344, 1016-1019.

Poulsen C.J., Ehlers T.A., Insel N., Gregory-Wodzicki K., Ghosh P., Garzione C.N., Eiler J.M., Garzione C., Molnar P., Libarkin J., Macfadden B., Hartley A.J., Sempere T., Worner G., Barnes J.B., Ehlers T.A., Mamani M., Wörner G., Sempere T., Kowalski E., et al. (1999) A comparison of the taxonomic richness of vascular plants in China and the United States. The American Naturalist, 154, 160-181.

Qian H. \& Ricklefs R.E. (2000) Large-scale processes and the Asian bias in species diversity of temperate plants. Nature, 407, 180-182.

Quinn G.P. \& Keough M.J. (2002) Experimental designs and data analysis for biologists. 
Cambridge University Press, Cambridge.

Rahbek C. (1995) The elevational gradient of species richness: a uniform pattern? Ecography, 18, 200-205.

Ramstein G., Fluteau F., Besse J., \& Joussaume S. (1997) Effect of orogeny, plate motion and land-sea distribution on Eurasian climate change over the past 30 million years. Nature, 386, $788-795$.

Raymo M.E. \& Ruddiman W.F. (1992) Tectonic forcing of Late Cenozoic climate. Nature, 359, 117-122.

Rodríguez M.Á., Belmontes J.A., \& Hawkins B.A. (2005) Energy, water and large-scale patterns of reptile and amphibian species richness in Europe. Acta Oecologica, 28, 6570.

Ron S.R. (2000) Biogeographic area relationships of lowland Neotropical rainforest based on raw distributions of vertebrate groups. Biological Journal of the Linnean Society, 71, 379-402.

Ruddiman W. (1997) Tectonic Uplift and Climate Change. Springer US, Boston, MA.

Sandel B., Arge L., Dalsgaard B., Davies R.G., Gaston K.J., Sutherland W.J., \& Svenning J.C. (2011) The influence of Late Quaternary climate-change velocity on species endemism. Science, 334, 660-664.

Sellwood B.W. \& Valdes P.J. (2006) Mesozoic climates: General circulation models and the rock record. Sedimentary geology, 190, 269-287.

Sepulchre P., Ramstein G., Fluteau F., Schuster M., Tiercelin J.-J., \& Brunet M. (2006) Tectonic uplift and Eastern Africa aridification. Science, 313, 1419-1423.

Simpson, G. (1980). Splendid isolation: the curious history of mammals in South America. Yale Univ. Press, New Haven.

Smith A., Smith D., \& Funnell B. (1994) Atlas of Mesozoic and Cenozoic Coast-lines. Cambridge University Press, Cambridge, United Kingdom.

Sniderman J.M.K., Pillans B., O’Sullivan P.B., \& Kershaw A.P. (2007) Climate and vegetation in southeastern Australia respond to Southern hemisphere insolation forcing in the Late Pliocene-early Pleistocene. Geology, 35, 41-44.

Trabucco A. \& Zomer R.. (2009) Available at: http://www.csi.cgiar.org.

IUCN (2015) The IUCN Red List of Threatened Species. Available at: http://www.iucnredlist.org. Downloaded on 10 January 2015.

Van Welzen P.C., Parnell J. a. N., \& Slik J.W.F. (2011) Wallace's line and plant distributions: two or three phytogeographical areas and where to group Java? Biological Journal of the Linnean Society, 103, 531-545.

Wallace A.R. (1860) On the zoological geography of the Malay archipelago. Journal of the Proceedings of the Linnean Society of London, Zoology, 4, 172-184.

Webb S.D. (2006) The great American biotic interchange: patterns and processes. Annals of the Missouri Botanical Garden, 93, 245-257.

Wiens J.J. \& Donoghue M.J. (2004) Historical biogeography, ecology and species richness. Trends in ecology \& evolution, 19, 639-644.

Wilson M.E. \& Rosen B.R. (1998) Implications of paucity of corals in the Paleogene of SE Asia: plate tectonics or centre of origin. Biogeography and geological evolution of SE 
Asia. pp. 165-195.

Woodburne M.O. (2010) The great American biotic interchange: Dispersals, tectonics, climate, sea level and holding pens. Journal of mammalian evolution, 17, 245-264.

Yoder A.D. \& Nowak M.D. (2006) Has vicariance or dispersal been the predominant biogeographic force in Madagascar? Only time will tell. Annual Review of Ecology, Evolution, and Systematics, 37, 405-431.

Zuur A.F., Ieno E.N., \& Elphick C.S. (2010) A protocol for data exploration to avoid common statistical problems. Methods in Ecology and Evolution, 1, 3-14. 


\section{SUPPORTING INFORMATION}

Additional Supporting Information may be found in the online version of this article:

Appendix S1 Supplemental tables and figures.

\section{BIOSKETCHES}

Patrice Descombes is a researcher at ETH Zurich and WSL Birmensdorf interested in understanding the distribution of biodiversity along spatial gradients. He is part of the research group "Landscape Ecology" at ETH Zurich directed by Prof. Loïc Pellissier. The objective of the research group is to understand the link between landscape dynamics and biodiversity.

Authors' contributions: PD designed the study and performed the data and statistical analyses.

FL participated in data and statistical analyses. $\mathrm{CH}$ prepared the plate tectonic data. LP designed and coordinated the study. PD wrote the first draft of the manuscript and FL, CA, $\mathrm{CH}$ and LP contributed to the writing. All authors gave final approval for publication.

Editor: Alexandre Antonelli 


\section{TABLES}

Table 1. Relationships between six predictive variables and total amphibian, bird or mammal richness in the Indo-Australian archipelago. LB (land-bridges history); LS (latitudinal shift history); CV (Late Quaternary climate-change velocity); NPP (net primary productivity); PET (potential evapo-transpiration); LH (landscape heterogeneity). The table shows the coefficients of determination $\left(R^{2}\right)$, the Akaike information criterion values $(A I C)$ and the standardized regression coefficients estimated from ordinary least squares multiple regressions (OLS) including all predictor variables (Full model). A simultaneous autoregressive (SAR) model was also used to estimate the standardized coefficients and their statistical significance after having accounted for the effect of spatial autocorrelation. As shown by the Moran's I global, spatial autocorrelation in model residuals was significantly reduced in the SAR model. The results of the minimum adequate model (MAM) are also shown for both the OLS and SAR models (i.e. the best model with the lowest AIC value). The relative importance of each predictor variable was assessed using the summed Akaike weights $\left(\mathrm{W}_{\mathrm{AIC}}\right) . . \mathrm{P}<0.1, * \mathrm{P}<0.05, * * \mathrm{P}<0.01, * * * \mathrm{P}<0.001$.

\begin{tabular}{|c|c|c|c|c|c|c|c|c|c|c|}
\hline & \multicolumn{5}{|c|}{ OLS } & \multicolumn{5}{|c|}{ SAR } \\
\hline & \multicolumn{2}{|c|}{ Full model } & \multicolumn{2}{|c|}{ MAM } & \multirow[t]{3}{*}{$\mathrm{W}_{\mathrm{AIC}}$} & \multicolumn{2}{|c|}{ Full model } & \multicolumn{2}{|c|}{ MAM } & $\mathrm{W}_{\text {AIC }}$ \\
\hline \multicolumn{10}{|l|}{ Amphibians } & \\
\hline \multicolumn{10}{|c|}{ Historical variables } & \\
\hline LB & 0.537 & $* * *$ & 0.581 & $* * *$ & 1 & 0.529 & $* *$ & 0.533 & $* *$ & 0.91 \\
\hline $\mathrm{LB}^{2}$ & -0.602 & $* * *$ & -0.633 & $* * *$ & 1 & -0.399 & $* *$ & -0.414 & $* *$ & 0.86 \\
\hline LS & -0.462 & $* * *$ & -0.477 & $* * *$ & 1 & -0.399 & $*$ & -0.184 & $* *$ & 0.98 \\
\hline $\mathrm{LS}^{2}$ & 0.175 & $*$ & 0.192 & $*$ & 0.8 & 0.191 & & & & 0.46 \\
\hline Velocity & 0.045 & & & & 0.66 & -0.129 & $*$ & -0.112 & $* * *$ & 1 \\
\hline Velocity $^{2}$ & -0.079 & & & & 0.24 & 0.027 & & & & 0.28 \\
\hline \multicolumn{11}{|c|}{ Contemporary variables } \\
\hline NPP & 0.848 & $* * *$ & 0.856 & $* * *$ & 1 & 0.025 & & 0.066 & $* *$ & 0.95 \\
\hline $\mathrm{NPP}^{2}$ & -0.411 & $* * *$ & -0.422 & $* * *$ & 1 & 0.036 & & & & 0.26 \\
\hline PET & -0.429 & & -0.391 & & 1 & 0.778 & . & 0.180 & $* * *$ & 1 \\
\hline $\mathrm{PET}^{2}$ & 0.534 & $*$ & 0.499 & & 0.78 & -0.600 & & & & 0.47 \\
\hline LH & 0.258 & $* * *$ & 0.267 & $* * *$ & 1 & 0.409 & $* * *$ & 0.410 & $* * *$ & 1 \\
\hline $\mathrm{LH}^{2}$ & -0.089 & & -0.096 & $*$ & 0.66 & -0.193 & $* * *$ & -0.194 & $* * *$ & 1 \\
\hline$R^{2}$ & 0.508 & $* * *$ & 0.508 & $* * *$ & & & & & & \\
\hline$A I C$ & 2839.4 & & 2838.4 & & & 1677.0 & & 1672.9 & & \\
\hline Moran's I & 0.076 & & 0.075 & & & 0.004 & & 0.005 & & \\
\hline
\end{tabular}

\section{Birds}

\section{Historical variables}

\begin{tabular}{|c|c|c|c|c|c|c|c|c|c|}
\hline LB & 0.884 & $* * *$ & 0.896 & $* * *$ & 1 & 0.765 & $* * *$ & 0.738 & $* * *$ \\
\hline $\mathrm{LB}^{2}$ & -0.815 & $* * *$ & -0.815 & $* * *$ & 1 & -0.557 & $* * *$ & -0.546 & $* * *$ \\
\hline LS & -0.721 & $* * *$ & -0.748 & $* * *$ & 1 & -0.406 & $* *$ & -0.243 & $* * *$ \\
\hline $\mathrm{LS}^{2}$ & 0.363 & $* * *$ & 0.388 & $* * *$ & 1 & 0.144 & & & \\
\hline Velocity & -0.100 & . & & & 0.56 & -0.025 & & & \\
\hline
\end{tabular}




\begin{tabular}{|c|c|c|c|c|c|c|c|c|c|c|}
\hline Velocity $^{2}$ & 0.084 & & & & 0.34 & 0.037 & & & & 0.12 \\
\hline \multicolumn{11}{|c|}{ Contemporary variables } \\
\hline NPP & 0.976 & $* * *$ & 0.980 & $* * *$ & 1 & 0.055 & & 0.096 & $* * *$ & \\
\hline $\mathrm{NPP}^{2}$ & -0.635 & $* * *$ & -0.647 & $* * *$ & 1 & 0.041 & & & & 0.29 \\
\hline PET & 1.295 & $* * *$ & 1.303 & $* * *$ & 1 & 1.071 & $* *$ & 0.967 & $* *$ & 0.96 \\
\hline $\mathrm{PET}^{2}$ & -1.157 & $* * *$ & -1.166 & $* * *$ & 1 & -1.010 & $* *$ & -0.917 & $* *$ & .89 \\
\hline LH & 0.280 & $* * *$ & 0.301 & $* * *$ & 1 & 0.388 & $* * *$ & 0.390 & $* * *$ & \\
\hline $\mathrm{LH}^{2}$ & -0.081 & $*$ & -0.094 & $* *$ & 0.88 & -0.217 & $* * *$ & -0.220 & $* * *$ & \\
\hline$R^{2}$ & 0.747 & $* * *$ & 0.747 & $* * *$ & & & & & & \\
\hline$A I C$ & 1956.6 & & 1955.9 & & & 1221.2 & & 1215.6 & & \\
\hline Moran's I & 0.061 & & 0.063 & & & 0.009 & & 0.009 & & \\
\hline
\end{tabular}

\section{Mammals}

Historical variables

\begin{tabular}{|c|c|c|c|c|c|c|c|c|c|c|}
\hline LB & 1.264 & $* * *$ & 1.277 & $* * *$ & 1 & 0.734 & $* * *$ & 0.689 & $* * *$ & 1 \\
\hline $\mathrm{LB}^{2}$ & -1.109 & $* * *$ & -1.114 & $* * *$ & 1 & -0.538 & $* * *$ & -0.507 & $* * *$ & 1 \\
\hline LS & -0.656 & $* * *$ & -0.673 & $* * *$ & 1 & -0.338 & $* *$ & -0.236 & $* * *$ & 1 \\
\hline $\mathrm{LS}^{2}$ & 0.204 & $* * *$ & 0.220 & $* * *$ & 1 & 0.076 & & & & 0.3 \\
\hline Velocity & -0.047 & & & & 0.4 & -0.062 & & -0.034 & . & 0.71 \\
\hline Velocity $^{2}$ & 0.033 & & & & 0.12 & 0.033 & & & & 0.2 \\
\hline
\end{tabular}

Contemporary variables

\begin{tabular}{|c|c|c|c|c|c|c|c|c|c|c|}
\hline NPP & 0.204 & $* *$ & 0.208 & $* *$ & 1 & -0.075 & & -0.071 & & \\
\hline $\mathrm{NPP}^{2}$ & 0.140 & & 0.132 & & 0.67 & 0.183 & $*$ & 0.180 & * & 0.85 \\
\hline PET & 0.540 & $* *$ & 0.550 & $* *$ & 1 & 0.616 & $*$ & 0.146 & $* * *$ & . \\
\hline $\mathrm{PET}^{2}$ & -0.404 & $*$ & -0.414 & $*$ & 0.85 & -0.483 & & & & 0.5 \\
\hline LH & 0.310 & $* * *$ & 0.323 & $* * *$ & 1 & 0.303 & $* * *$ & 0.303 & $* * *$ & \\
\hline $\mathrm{LH}^{2}$ & -0.137 & $* * *$ & -0.145 & $* * *$ & 1 & -0.161 & $* * *$ & -0.161 & $* * *$ & \\
\hline$R^{2}$ & 0.771 & $* * *$ & 0.772 & $* * *$ & & & & & & \\
\hline$A I C$ & 1823.1 & & 1820.1 & & & 783.8 & & 780.8 & & \\
\hline Moran's I & 0.073 & & 0.073 & & & 0.007 & & 0.007 & & \\
\hline
\end{tabular}


Table 2. Relationships between six predictive variables and total amphibian, bird or mammal richness in eastern Africa and Madagascar. See Table 1 for content information.

\begin{tabular}{|c|c|c|c|c|c|c|c|c|c|c|}
\hline & \multicolumn{5}{|c|}{ OLS } & \multicolumn{5}{|c|}{ SAR } \\
\hline & \multicolumn{2}{|c|}{ Full model } & \multicolumn{2}{|c|}{ MAM } & \multirow[t]{2}{*}{$\mathrm{W}_{\mathrm{AIC}}$} & \multicolumn{2}{|c|}{ Full model } & \multicolumn{2}{|c|}{ MAM } & $\mathrm{W}_{\mathrm{AIC}}$ \\
\hline \multicolumn{10}{|l|}{ Amphibians } & \\
\hline \multicolumn{11}{|c|}{ Historical variables } \\
\hline LB & 0.738 & $* * *$ & 0.714 & $* * *$ & 1 & 0.619 & $*$ & 0.638 & $*$ & 0.86 \\
\hline $\mathrm{LB}^{2}$ & -0.675 & $* * *$ & -0.651 & $* * *$ & 1 & -0.491 & & -0.516 & & 0.48 \\
\hline LS & -0.650 & $* * *$ & -0.650 & $* * *$ & 1 & 0.315 & $*$ & 0.309 & $*$ & 0.91 \\
\hline $\mathrm{LS}^{2}$ & 0.598 & $* * *$ & 0.594 & $* * *$ & 1 & -0.361 & $* *$ & -0.355 & $* *$ & 0.87 \\
\hline Velocity & 0.027 & & & & 0.42 & -0.090 & & -0.077 & $* * *$ & 1 \\
\hline Velocity ${ }^{2}$ & -0.051 & & & & 0.12 & 0.015 & & & & 0.27 \\
\hline \multicolumn{11}{|c|}{ Contemporary variables } \\
\hline NPP & 1.140 & $* * *$ & 1.134 & $* * *$ & 1 & -0.234 & $*$ & -0.210 & & 1 \\
\hline $\mathrm{NPP}^{2}$ & -0.490 & $* * *$ & -0.484 & $* * *$ & 1 & 0.347 & $* * *$ & 0.329 & $* *$ & 0.99 \\
\hline PET & 1.007 & $* *$ & 0.983 & $* *$ & 0.97 & -0.087 & & -0.183 & $* * *$ & 1 \\
\hline $\mathrm{PET}^{2}$ & -1.027 & $* * *$ & -1.007 & $* *$ & 0.96 & -0.104 & & & & 0.28 \\
\hline LH & -0.015 & & & & 0.33 & 0.131 & $* *$ & 0.070 & $* * *$ & 1 \\
\hline $\mathrm{LH}^{2}$ & 0.007 & & & & 0.09 & -0.052 & & & & 0.5 \\
\hline$R^{2}$ & 0.497 & $* * *$ & 0.498 & $* * *$ & & & & & & \\
\hline$A I C$ & 2299.1 & & 2292.1 & & & 1179.0 & & 1175.2 & & \\
\hline Moran's I & 0.073 & & 0.073 & & & 0.004 & & 0.004 & & \\
\hline
\end{tabular}

\section{Birds}

Historical variables

\begin{tabular}{|c|c|c|c|c|c|c|c|c|c|c|}
\hline LB & 0.922 & $* * *$ & 0.946 & $* * *$ & 1 & 0.204 & & 0.152 & . & 0.68 \\
\hline $\mathrm{LB}^{2}$ & -1.273 & $* * *$ & -1.292 & $* * *$ & 1 & -0.074 & & & & 0.18 \\
\hline LS & -0.123 & & -0.124 & $* * *$ & 1 & -0.013 & & & & 0.34 \\
\hline $\mathrm{LS}^{2}$ & -0.003 & & & & 0.26 & 0.002 & & & & 0.09 \\
\hline Velocity & -0.485 & $* * *$ & -0.481 & $* * *$ & 1 & -0.005 & & -0.041 & $* *$ & 0.97 \\
\hline Velocity $^{2}$ & 0.360 & $* * *$ & 0.348 & $* * *$ & 1 & -0.037 & & & & 0.33 \\
\hline \multicolumn{11}{|c|}{ Contemporary variables } \\
\hline NPP & 1.112 & $* * *$ & 1.119 & $* * *$ & 1 & -0.223 & $* *$ & -0.224 & $* *$ & 0.99 \\
\hline $\mathrm{NPP}^{2}$ & -0.681 & $* * *$ & -0.688 & $* * *$ & 1 & 0.229 & $* * *$ & 0.230 & $* * *$ & 0.98 \\
\hline PET & 1.298 & $* * *$ & 1.293 & $* * *$ & 1 & -0.125 & & -0.046 & $*$ & 0.82 \\
\hline $\mathrm{PET}^{2}$ & -1.189 & $* * *$ & -1.183 & $* * *$ & 1 & 0.082 & & & & 0.23 \\
\hline LH & 0.305 & $* * *$ & 0.237 & $* * *$ & 1 & 0.116 & $* * *$ & 0.116 & $* * *$ & 1 \\
\hline $\mathrm{LH}^{2}$ & -0.068 & & & & 0.42 & -0.060 & $* *$ & -0.060 & $* *$ & 0.91 \\
\hline$R^{2}$ & 0.575 & $* * *$ & 0.575 & $* * *$ & & & & & & \\
\hline$A I C$ & 2120.6 & & 2118.0 & & & 235.9 & & 227.0 & & \\
\hline Moran's I & 0.108 & & 0.108 & & & 0.005 & & 0.005 & & \\
\hline
\end{tabular}

\section{Mammals}

Historical variables 


\begin{tabular}{|c|c|c|c|c|c|c|c|c|c|c|}
\hline LB & 0.448 & $* * *$ & 0.487 & $* * *$ & 1 & 0.143 & & & & 0.47 \\
\hline $\mathrm{LB}^{2}$ & -0.801 & $* * *$ & -0.834 & $* * *$ & 1 & -0.088 & & & & 0.14 \\
\hline LS & -0.353 & $* * *$ & -0.345 & $* * *$ & 1 & 0.028 & & & & 0.34 \\
\hline $\mathrm{LS}^{2}$ & 0.167 & * & 0.163 & * & 0.85 & -0.028 & & & & 0.1 \\
\hline Velocity & -0.234 & $* *$ & -0.124 & $* * *$ & 1 & -0.026 & & -0.038 & $* * *$ & 1 \\
\hline Velocity $^{2}$ & 0.121 & & & & 0.44 & -0.013 & & & & 0.28 \\
\hline \multicolumn{11}{|c|}{ Contemporary variables } \\
\hline NPP & 0.759 & $* * *$ & 0.765 & $* * *$ & 1 & -0.012 & & 0.056 & $* * *$ & 1 \\
\hline $\mathrm{NPP}^{2}$ & -0.232 & $* *$ & -0.238 & $* *$ & 0.93 & 0.065 & & & & 0.43 \\
\hline PET & 1.650 & $* * *$ & 1.613 & $* * *$ & 1 & 0.255 & . & 0.257 & . & 0.64 \\
\hline $\mathrm{PET}^{2}$ & -1.624 & $* * *$ & -1.586 & $* * *$ & 1 & -0.280 & $*$ & -0.281 & $*$ & 0.46 \\
\hline LH & 0.248 & $* * *$ & 0.168 & $* * *$ & 1 & 0.122 & $* * *$ & 0.118 & $* * *$ & 1 \\
\hline $\mathrm{LH}^{2}$ & -0.085 & & & & 0.52 & -0.052 & $* *$ & -0.050 & $* *$ & 0.94 \\
\hline$R^{2}$ & 0.608 & $* * *$ & 0.607 & $* * *$ & & & & & & \\
\hline$A I C$ & 2034.1 & & 2033.9 & & & -218.8 & & -227.5 & & \\
\hline Moran's I & 0.127 & & 0.127 & & & 0.006 & & 0.006 & & \\
\hline
\end{tabular}




\section{FIGURES}
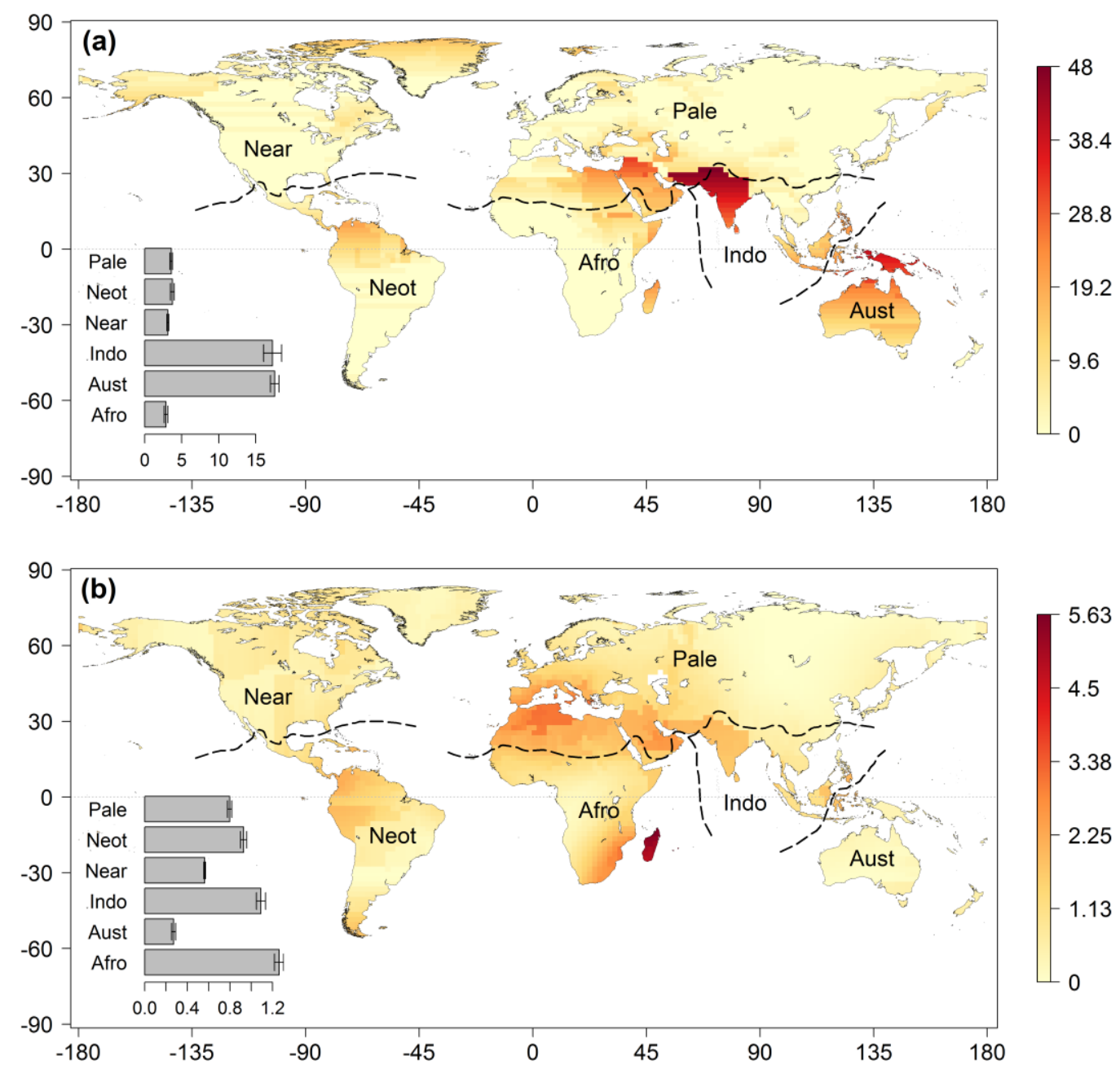

Figure 1. Historical variables derived from plate tectonics since the Early Cretaceous $(\sim 140$ Ma). (a) The latitudinal shift history variable represents the cumulative latitudinal distances crossed by a given land patch under plate motion. (b) The land-bridges history variable represents the cumulative potential for dispersal across disconnected land masses separated by sea barriers since the Early Cretaceous. Barplots show the variability (mean \pm SE) of the two variables in six different biogeographic realms $($ Pale $=$ Palaearctic, Neot $=$ Neotropic, Near $=$ Nearctic, Indo = Into-Malay, Aust $=$ Australasia, Afro $=$ Afrotropic $).$ High values (red colour $)$ highlight land masses that (a) underwent strong latitudinal shift or (b) showed the highest potential for allopatric speciation to shape species richness across sea barriers. 

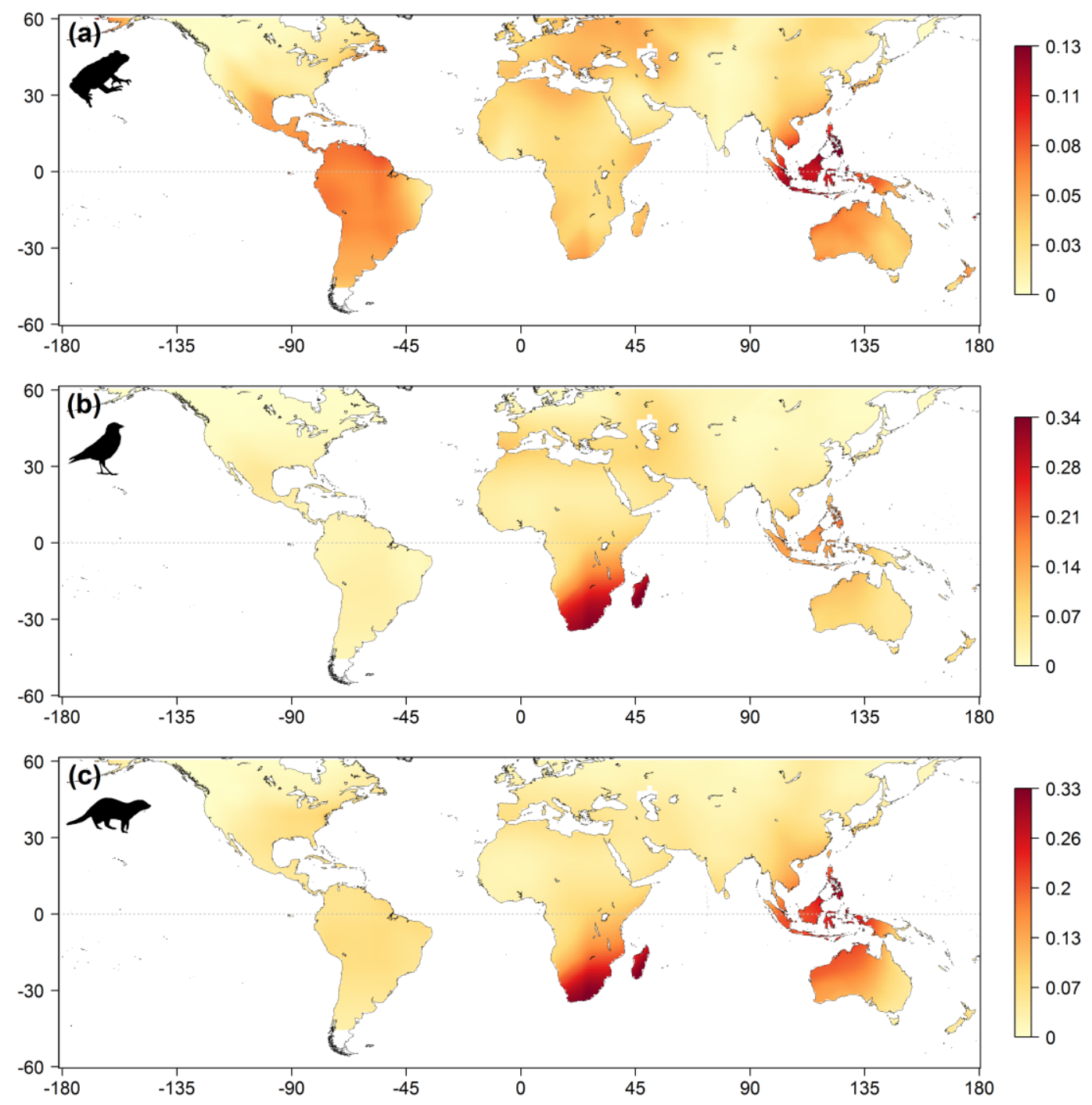

Figure 2. Mean relative regional importance of plate motion history (i.e. latitudinal shift history and land-bridges history variables combined) in explaining species richness variation for (a) amphibians, (b) birds and (c) mammals. Values correspond to the mean independent proportion of explained variance assessed by variance partitioning in OLS models (full model including all predictor variables) and performed over different regions (square focal moving windows of various sizes). The variance partitioning value of each of the mobile windows was attributed to the $1^{\circ}$ cell at its centre. High values (red colour) indicate a large contribution of the plate motion history in explaining species richness patterns. Note that the scales are different between the three panels. 
(a)<smiles>C1C[C-]2C[C]1C2</smiles>

Accipitriformes Anseriformes Caprimulgiformes Charadriiformes Ciconiiformes Columbiformes Coraciiformes Cuculiformes Falconiformes Galliformes Gruiformes Passeriformes Pelecaniformes Piciformes Procellariiformes Psittaciformes Strigiformes Suliformes Carnivora Cetartiodactyla Chiroptera Dasyuromorphia Diprotodontia Eulipotyphla Lagomorpha Primates Rodentia Scandentia
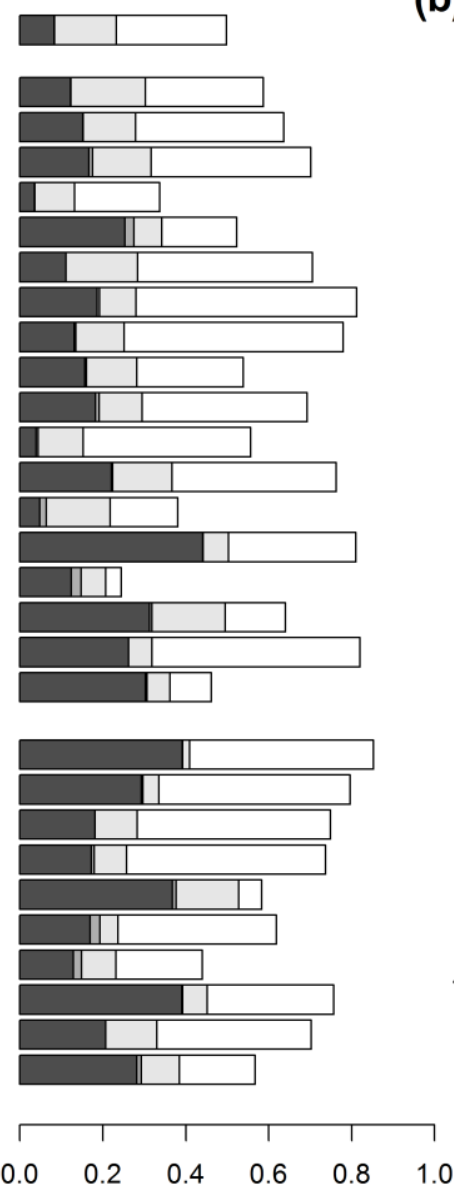

Relative contribution (b)

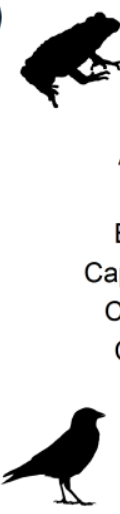
Anura
Gymnophiona Accipitriformes Anseriformes Bucerotiformes Caprimulgiformes Charadriiformes Columbiformes Coraciiformes Cuculiformes Falconiformes Galliformes Gruiformes Passeriformes Pelecaniformes Piciformes Procellariiformes Strigiformes Suliformes

Afrosoricida Carnivora Cetartiodactyla

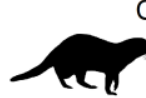

Chiroptera Eulipotyphla Primates Rodentia
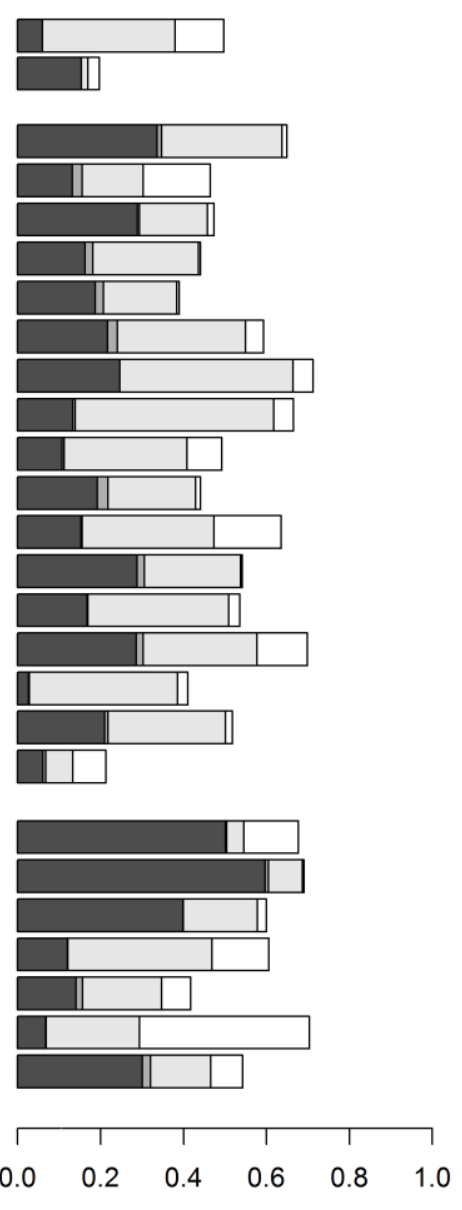

Relative contribution

Figure 3. Relative importance of plate motion history (dark grey; latitudinal shift history and land-bridges history), Late Quaternary climate-change velocity (grey) and contemporary (light grey; net primary productivity, potential evapo-transpiration and landscape heterogeneity) variables in explaining species richness variation in (a) the Indo-Australian Archipelago (IAA) and (b) eastern Africa and Madagascar for amphibians, birds and mammals and different taxonomic groups (Orders). Values correspond to the independent proportion of explained variance in OLS models (full model including all predictor variables; see Table S3 and S4 in Appendix S1) assessed by variance partitioning. The shared contributions of the variables in the model are shown in white. 
Original article for Journal of Biogeography

Spatial imprints of plate tectonics on extant richness of terrestrial vertebrates

Patrice Descombes ${ }^{*}$, Fabien Leprieur, Camille Albouy, Christian Heine, Loïc Pellissier

* Author for correspondence: Patrice Descombes, Swiss Federal Research Institute WSL, 8903 Birmensdorf, Switzerland, patrice.descombes@wsl.ch

SUPPORTING INFORMATION 
Table S1. Relationships between six predictive variables and total amphibian, bird or mammal richness at the global scale. LE (land exchanges); LS (latitudinal shift); CV (Late Quaternary climate-change velocity); NPP (net primary productivity); PET (potential evapotranspiration); LH (landscape heterogeneity). The table shows the coefficients of determination $\left(R^{2}\right)$, the Akaike information criterion values $(A I C)$ and the standardized regression coefficients estimated from ordinary least squares multiple regressions (OLS) including all predictor variables (Full model). The $R^{2}$ and AIC values are highlighted in bold. A simultaneous autoregressive (SAR) model was also used to estimate the standardized coefficients and their statistical significance after having accounted for the effect of spatial autocorrelation. As shown by the Moran's I global, spatial autocorrelation in model residuals was significantly reduced in the SAR model. The results of the minimum adequate model (MAM) are also shown for both the OLS and SAR models (i.e. the best model with the lowest AIC value). The relative importance of each predictor variable was assessed using the summed Akaike weights $\left(\mathrm{W}_{\mathrm{AIC}}\right) .(*) \mathrm{P}<0.1, * \mathrm{P}<0.05, * * \mathrm{P}<0.01, * * * \mathrm{P}<0.001$.

\begin{tabular}{|c|c|c|c|c|c|c|c|c|c|c|}
\hline & \multicolumn{5}{|c|}{ OLS } & \multicolumn{5}{|c|}{ SAR } \\
\hline & \multicolumn{2}{|c|}{ Full model } & \multicolumn{2}{|l|}{ MAM } & \multirow[t]{2}{*}{$\mathrm{W}_{\mathrm{AIC}}$} & \multicolumn{2}{|c|}{ Full model } & \multirow{2}{*}{\multicolumn{2}{|c|}{ MAM }} & $\mathrm{W}_{\mathrm{AIC}}$ \\
\hline \multicolumn{8}{|l|}{ Amphibians } & & & \\
\hline \multicolumn{11}{|c|}{ Historical variables } \\
\hline LE & 0.127 & $* * *$ & 0.127 & $* * *$ & 1 & 0.049 & $(*)$ & & & 0.57 \\
\hline $\mathrm{LE}^{2}$ & -0.100 & $* * *$ & -0.101 & $* * *$ & 1 & -0.047 & $(*)$ & & & 0.35 \\
\hline LS & -0.144 & $* * *$ & -0.144 & $* * *$ & 1 & -0.019 & & -0.012 & & 0.63 \\
\hline $\mathrm{LS}^{2}$ & 0.042 & $* * *$ & 0.043 & $* * *$ & 1 & 0.006 & & & & 0.18 \\
\hline Velocity & -0.006 & & -0.014 & * & 0.91 & -0.032 & $*$ & -0.032 & $*$ & 0.81 \\
\hline Velocity $^{2}$ & -0.007 & & & & 0.27 & 0.021 & $*$ & 0.022 & $*$ & 0.6 \\
\hline \multicolumn{11}{|c|}{ Contemporary variables } \\
\hline NPP & 0.428 & $* * *$ & 0.428 & $* * *$ & 1 & -0.043 & $* *$ & -0.043 & $* *$ & 1 \\
\hline $\mathrm{NPP}^{2}$ & 0.346 & $* * *$ & 0.346 & $* * *$ & 1 & 0.119 & $* * *$ & 0.119 & $* * *$ & 1 \\
\hline PET & 0.186 & $* * *$ & 0.185 & $* * *$ & 1 & 0.243 & $* * *$ & 0.244 & $* * *$ & 1 \\
\hline $\mathrm{PET}^{2}$ & -0.072 & $* *$ & -0.072 & $* *$ & 0.93 & -0.089 & & -0.089 & & 0.52 \\
\hline LH & -0.137 & $* * *$ & -0.138 & $* * *$ & 1 & 0.074 & $* * *$ & 0.074 & $* * *$ & 1 \\
\hline $\mathrm{LH}^{2}$ & 0.082 & $* * *$ & 0.083 & $* * *$ & 1 & -0.036 & $* * *$ & -0.036 & $* * *$ & 1 \\
\hline$R^{2}$ & 0.685 & $* * *$ & 0.685 & $* * *$ & & & & & & \\
\hline$A I C$ & 26180.6 & & 26178.9 & & & -4575.0 & & -4577.1 & & \\
\hline Moran's I & 0.095 & & 0.095 & & & 0.001 & & 0.001 & & \\
\hline
\end{tabular}

\section{Birds}

Historical variables

\begin{tabular}{|c|c|c|c|c|c|c|c|c|}
\hline LE & 0.189 & $* * *$ & 0.189 & $* * *$ & 1 & 0.013 & & 0.35 \\
\hline $\mathrm{LE}^{2}$ & -0.259 & $* * *$ & -0.259 & $* * *$ & 1 & -0.016 & & 0.11 \\
\hline LS & -0.211 & $* * *$ & -0.211 & $* * *$ & 1 & 0.020 & 0.021 & 0.64 \\
\hline $\mathrm{LS}^{2}$ & 0.154 & $* * *$ & 0.154 & $* * *$ & 1 & $-0.025(*)$ & $-0.026(*)$ & 0.43 \\
\hline Velocity & -0.064 & $* * *$ & -0.064 & $* * *$ & 1 & -0.018 & & 0.45 \\
\hline Velocity ${ }^{2}$ & 0.024 & $(*)$ & 0.024 & $(*)$ & 0.71 & 0.015 & & 0.23 \\
\hline \multicolumn{9}{|c|}{ Contemporary variables } \\
\hline NPP & 0.994 & $* * *$ & 0.994 & $* * *$ & 1 & -0.011 & -0.011 & \\
\hline
\end{tabular}




\begin{tabular}{|c|c|c|c|c|c|c|c|c|c|}
\hline$N^{\prime} P^{2}$ & -0.330 & $* * *$ & -0.330 & $* * *$ & 1 & 0.117 & $* * *$ & 0.117 & $* * *$ \\
\hline PET & 0.473 & $* * *$ & 0.473 & $* * *$ & 1 & 0.263 & $* * *$ & 0.194 & $* * *$ \\
\hline $\mathrm{PET}^{2}$ & -0.218 & $* * *$ & -0.218 & $* * *$ & 1 & -0.059 & & & \\
\hline LH & -0.001 & & -0.001 & & 1 & 0.076 & $* * *$ & 0.077 & $* * *$ \\
\hline $\mathrm{LH}^{2}$ & 0.057 & $* * *$ & 0.057 & $* * *$ & 1 & -0.026 & $* * *$ & -0.026 & $* * *$ \\
\hline$R^{2}$ & 0.749 & $* * *$ & 0.749 & $* * *$ & & & & & \\
\hline$A I C$ & 22646.2 & & 22646.2 & & & -4975.1 & & -4981.5 & \\
\hline Moran's I & 0.084 & & 0.084 & & & 0.001 & & 0.001 & \\
\hline
\end{tabular}

\section{Mammals}

Historical variables

\begin{tabular}{|c|c|c|c|c|c|c|c|c|c|c|}
\hline LE & 0.253 & $* * *$ & 0.253 & $* * *$ & 1 & 0.005 & & & & 0.49 \\
\hline $\mathrm{LE}^{2}$ & -0.277 & $* * *$ & -0.277 & $* * *$ & 1 & -0.017 & & & & 0.17 \\
\hline LS & -0.291 & $* * *$ & -0.291 & $* * *$ & 1 & 0.011 & & & & 0.37 \\
\hline $\mathrm{LS}^{2}$ & 0.135 & $* * *$ & 0.135 & $* * *$ & 1 & -0.008 & & & & 0.12 \\
\hline Velocity & -0.134 & $* * *$ & -0.134 & $* * *$ & 1 & -0.045 & $* * *$ & -0.045 & $* * *$ & 1 \\
\hline Velocity $^{2}$ & 0.077 & $* * *$ & 0.077 & $* * *$ & 1 & 0.030 & $* * *$ & 0.029 & $* * *$ & 0.99 \\
\hline \multicolumn{11}{|c|}{ Contemporary variables } \\
\hline NPP & 0.551 & $* * *$ & 0.551 & $* * *$ & 1 & 0.030 & * & 0.029 & $*$ & 1 \\
\hline $\mathrm{NPP}^{2}$ & 0.157 & $* * *$ & 0.157 & $* * *$ & 1 & 0.074 & $* * *$ & 0.075 & $* * *$ & 1 \\
\hline PET & 0.430 & $* * *$ & 0.430 & $* * *$ & 1 & 0.382 & $* * *$ & 0.379 & $* * *$ & 1 \\
\hline $\mathrm{PET}^{2}$ & -0.230 & $* * *$ & -0.230 & $* * *$ & 1 & -0.091 & $(*)$ & -0.090 & $(*)$ & 0.67 \\
\hline $\mathrm{LH}$ & 0.064 & $* * *$ & 0.064 & $* * *$ & 1 & 0.084 & $* * *$ & 0.084 & $* * *$ & 1 \\
\hline $\mathrm{LH}^{2}$ & -0.018 & $(*)$ & -0.018 & $(*)$ & 0.7 & -0.039 & $* * *$ & -0.039 & $* * *$ & 1 \\
\hline$R^{2}$ & 0.738 & $* * *$ & 0.738 & $* * *$ & & & & & & \\
\hline IIC & 23327.4 & & 23327.4 & & & -11334.2 & & -11339.8 & & \\
\hline Ioran's I & 0.102 & & 0.102 & & & 0.000 & & 0.000 & & \\
\hline
\end{tabular}


Table S2. Relative contribution of contemporary (NPP = net primary productivity; PET = potential evapo-transpiration; $\mathrm{LH}=$ landscape heterogeneity) and historical (LS = latitudinal shift LE = land exchanges; CV = Late Quaternary climate-change velocity) variables in explaining species richness variation at the global level for amphibians, birds and mammals and different taxonomic orders. Values correspond to the independent proportion of explained variance in OLS full models.

\begin{tabular}{|c|c|c|c|c|}
\hline & \multirow{2}{*}{$\begin{array}{c}\begin{array}{c}\text { Contemporary } \\
\text { variables }\end{array} \\
\mathrm{NPP}+\mathrm{PET}+\mathrm{LH} \\
\end{array}$} & \multicolumn{2}{|c|}{ Historical variables } & \multirow{2}{*}{$\begin{array}{l}\mathrm{R}^{2} \text { full } \\
\text { model }\end{array}$} \\
\hline & & LS+LE & $\mathrm{CV}$ & \\
\hline Amphibians & 0.6249 & 0.0103 & 0.0001 & 0.6854 \\
\hline ANURA & 0.6173 & 0.0088 & 0.0012 & 0.6891 \\
\hline CAUDATA & 0.1256 & 0.0067 & 0.0474 & 0.2078 \\
\hline GYMNOPHIONA & 0.3602 & 0.0162 & 0.0034 & 0.4221 \\
\hline Birds & 0.6345 & 0.0224 & 0.0011 & 0.7493 \\
\hline ACCIPITRIFORMES & 0.4360 & 0.0321 & 0.0057 & 0.6061 \\
\hline ANSERIFORMES & 0.2104 & 0.0457 & 0.0149 & 0.4704 \\
\hline BUCEROTIFORMES & 0.2051 & 0.0503 & 0.0114 & 0.3311 \\
\hline CAPRIMULGIFORMES & 0.4854 & 0.0129 & 0.0009 & 0.5940 \\
\hline CHARADRIIFORMES & 0.2110 & 0.0263 & 0.0006 & 0.2491 \\
\hline CICONIIFORMES & 0.3028 & 0.0567 & 0.0156 & 0.5065 \\
\hline COLUMBIFORMES & 0.5393 & 0.0399 & 0.0009 & 0.7106 \\
\hline CORACIIFORMES & 0.4056 & 0.0166 & 0.0092 & 0.5587 \\
\hline CUCULIFORMES & 0.5780 & 0.0118 & 0.0139 & 0.7000 \\
\hline FALCONIFORMES & 0.2554 & 0.0161 & 0.0070 & 0.3710 \\
\hline GALLIFORMES & 0.2508 & 0.0248 & 0.0018 & 0.3176 \\
\hline GRUIFORMES & 0.5418 & 0.0228 & 0.0026 & 0.6101 \\
\hline PASSERIFORMES & 0.5985 & 0.0275 & 0.0000 & 0.7021 \\
\hline PELECANIFORMES & 0.5902 & 0.0071 & 0.0023 & 0.7129 \\
\hline PICIFORMES & 0.5704 & 0.0465 & 0.0020 & 0.6651 \\
\hline PROCELLARIIFORMES & 0.0498 & 0.0187 & 0.0257 & 0.0657 \\
\hline PSITTACIFORMES & 0.4300 & 0.0612 & 0.0010 & 0.5689 \\
\hline STRIGIFORMES & 0.4364 & 0.0436 & 0.0006 & 0.5230 \\
\hline STRUTHIONIFORMES & 0.3445 & 0.0268 & 0.0025 & 0.3915 \\
\hline SULIFORMES & 0.2599 & 0.1152 & 0.0056 & 0.4573 \\
\hline TROGONIFORMES & 0.4640 & 0.0329 & 0.0029 & 0.5762 \\
\hline Mammals & 0.6046 & 0.0374 & 0.0026 & 0.7381 \\
\hline AFROSORICIDA & 0.0463 & 0.4693 & 0.0077 & 0.5087 \\
\hline CARNIVORA & 0.2064 & 0.1476 & 0.0080 & 0.4197 \\
\hline CETARTIODACTYLA & 0.1914 & 0.1062 & 0.0260 & 0.3960 \\
\hline CHIROPTERA & 0.5822 & 0.0230 & 0.0036 & 0.7335 \\
\hline CINGULATA & 0.3165 & 0.0258 & 0.0019 & 0.3472 \\
\hline DASYUROMORPHIA & 0.0656 & 0.2987 & 0.0032 & 0.3600 \\
\hline DIDELPHIMORPHIA & 0.3568 & 0.0161 & 0.0007 & 0.4000 \\
\hline DIPROTODONTIA & 0.0306 & 0.2265 & 0.0018 & 0.2573 \\
\hline
\end{tabular}




$\begin{array}{lllll}\text { EULIPOTYPHLA } & 0.1288 & 0.0488 & 0.0026 & 0.2703 \\ \text { LAGOMORPHA } & 0.1722 & 0.0737 & 0.0016 & 0.3353 \\ \text { PRIMATES } & 0.5290 & 0.0215 & 0.0072 & 0.6229 \\ \text { RODENTIA } & 0.4544 & 0.0778 & 0.0030 & 0.5529 \\ \text { SCANDENTIA } & 0.0605 & 0.0315 & 0.0006 & 0.1034\end{array}$


Table S3. Relative contribution of contemporary (NPP = net primary productivity; PET = potential evapo-transpiration; $\mathrm{LH}=$ landscape heterogeneity) and historical (LS = latitudinal shift; LE = land exchanges; CV = Late Quaternary climate-change velocity) variables in explaining species richness variation in the Indo-Australian Archipelago (IAA) for amphibians, birds and mammals and different taxonomic orders. Values correspond to the independent proportion of explained variance in OLS full models.

\begin{tabular}{|c|c|c|c|c|}
\hline & \multirow{2}{*}{ 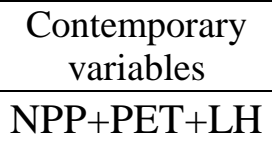 } & \multicolumn{2}{|c|}{ Historical variables } & \multirow{2}{*}{$\begin{array}{l}\mathrm{R}^{2} \text { full } \\
\text { model }\end{array}$} \\
\hline & & LS+LE & $\mathrm{CV}$ & \\
\hline Amphibians & 0.1395 & 0.0893 & 0.0004 & 0.5081 \\
\hline ANURA & 0.1492 & 0.0829 & 0.0004 & 0.4982 \\
\hline Birds & 0.1535 & 0.1439 & 0.0002 & 0.7471 \\
\hline ACCIPITRIFORMES & 0.1799 & 0.1222 & 0.0008 & 0.5873 \\
\hline ANSERIFORMES & 0.1257 & 0.1520 & 0.0008 & 0.6367 \\
\hline CAPRIMULGIFORMES & 0.1403 & 0.1660 & 0.0097 & 0.7012 \\
\hline CHARADRIIFORMES & 0.0962 & 0.0356 & 0.0003 & 0.3374 \\
\hline CICONIIFORMES & 0.0671 & 0.2531 & 0.0220 & 0.5233 \\
\hline COLUMBIFORMES & 0.1729 & 0.1109 & -0.0003 & 0.7057 \\
\hline CORACIIFORMES & 0.0887 & 0.1862 & 0.0055 & 0.8120 \\
\hline CUCULIFORMES & 0.1173 & 0.1312 & 0.0033 & 0.7794 \\
\hline FALCONIFORMES & 0.1216 & 0.1569 & 0.0033 & 0.5383 \\
\hline GALLIFORMES & 0.1037 & 0.1818 & 0.0089 & 0.6926 \\
\hline GRUIFORMES & 0.1086 & 0.0387 & 0.0053 & 0.5567 \\
\hline PASSERIFORMES & 0.1425 & 0.2209 & 0.0031 & 0.7630 \\
\hline PELECANIFORMES & 0.1543 & 0.0483 & 0.0156 & 0.3808 \\
\hline PICIFORMES & 0.0613 & 0.4406 & 0.0010 & 0.8103 \\
\hline PROCELLARIIFORMES & 0.0971 & 0.1235 & 0.0237 & 0.2070 \\
\hline PSITTACIFORMES & 0.1774 & 0.3123 & 0.0058 & 0.6406 \\
\hline STRIGIFORMES & 0.0565 & 0.2625 & -0.0002 & 0.8196 \\
\hline SULIFORMES & 0.0556 & 0.3028 & 0.0033 & 0.4614 \\
\hline Mammals & 0.1136 & 0.2407 & -0.0002 & 0.7713 \\
\hline CARNIVORA & 0.0171 & 0.3915 & 0.0010 & 0.8524 \\
\hline CETARTIODACTYLA & 0.0388 & 0.2926 & 0.0043 & 0.7967 \\
\hline CHIROPTERA & 0.1009 & 0.1819 & -0.0003 & 0.7487 \\
\hline DASYUROMORPHIA & 0.0784 & 0.1721 & 0.0071 & 0.7368 \\
\hline DIPROTODONTIA & 0.1508 & 0.3680 & 0.0087 & 0.5828 \\
\hline EULIPOTYPHLA & 0.0431 & 0.1692 & 0.0239 & 0.6188 \\
\hline LAGOMORPHA & 0.0833 & 0.1286 & 0.0197 & 0.4403 \\
\hline PRIMATES & 0.0594 & 0.3904 & 0.0017 & 0.7569 \\
\hline RODENTIA & 0.1240 & 0.2064 & 0.0002 & 0.7025 \\
\hline SCANDENTIA & 0.0915 & 0.2824 & 0.0103 & 0.5674 \\
\hline
\end{tabular}


Table S4. Relative contribution of contemporary (NPP = net primary productivity; PET = potential evapo-transpiration; $\mathrm{LH}=$ landscape heterogeneity) and historical (LS = latitudinal shift; LE = land exchanges; CV = Late Quaternary climate-change velocity) variables in explaining species richness variation in eastern Africa and Madagascar for amphibians, birds and mammals and different taxonomic orders. Values correspond to the independent proportion of explained variance in OLS full models.

\begin{tabular}{|c|c|c|c|c|}
\hline & \multirow{2}{*}{$\begin{array}{c}\begin{array}{c}\text { Contemporary } \\
\text { variables }\end{array} \\
\mathrm{NPP}+\mathrm{PET}+\mathrm{LH}\end{array}$} & \multicolumn{2}{|c|}{ Historical variables } & \multirow{2}{*}{$\begin{array}{l}\mathrm{R}^{2} \text { full } \\
\text { model }\end{array}$} \\
\hline & & $\mathrm{LS}+\mathrm{LE}$ & $\mathrm{CV}$ & \\
\hline Amphibians & 0.3228 & 0.0613 & -0.0005 & 0.4969 \\
\hline ANURA & 0.3206 & 0.0601 & -0.0005 & 0.4976 \\
\hline GYMNOPHIONA & 0.0434 & 0.1535 & -0.0003 & 0.1695 \\
\hline Birds & 0.2776 & 0.2981 & 0.0164 & 0.5748 \\
\hline ACCIPITRIFORMES & 0.2899 & 0.3365 & 0.0108 & 0.6487 \\
\hline ANSERIFORMES & 0.1468 & 0.1318 & 0.0238 & 0.4643 \\
\hline BUCEROTIFORMES & 0.1792 & 0.2890 & 0.0048 & 0.4579 \\
\hline CAPRIMULGIFORMES & 0.2600 & 0.1626 & 0.0184 & 0.4361 \\
\hline CHARADRIIFORMES & 0.1761 & 0.1870 & 0.0202 & 0.3891 \\
\hline COLUMBIFORMES & 0.3092 & 0.2167 & 0.0237 & 0.5932 \\
\hline CORACIIFORMES & 0.4181 & 0.2465 & -0.0005 & 0.7120 \\
\hline CUCULIFORMES & 0.4790 & 0.1331 & 0.0052 & 0.6649 \\
\hline FALCONIFORMES & 0.2965 & 0.1076 & 0.0045 & 0.4927 \\
\hline GALLIFORMES & 0.2228 & 0.1916 & 0.0260 & 0.4286 \\
\hline GRUIFORMES & 0.3183 & 0.1529 & 0.0024 & 0.6358 \\
\hline PASSERIFORMES & 0.2353 & 0.2883 & 0.0176 & 0.5373 \\
\hline PELECANIFORMES & 0.3667 & 0.1678 & 0.0011 & 0.5090 \\
\hline PICIFORMES & 0.2739 & 0.2862 & 0.0169 & 0.6986 \\
\hline PROCELLARIIFORMES & 0.3576 & 0.0260 & 0.0020 & 0.4104 \\
\hline STRIGIFORMES & 0.2834 & 0.2096 & 0.0080 & 0.5175 \\
\hline SULIFORMES & 0.0658 & 0.0605 & 0.0067 & 0.2125 \\
\hline Mammals & 0.2714 & 0.2625 & 0.0084 & 0.6080 \\
\hline AFROSORICIDA & 0.0411 & 0.5013 & 0.0029 & 0.6771 \\
\hline CARNIVORA & 0.0820 & 0.5973 & 0.0074 & 0.6902 \\
\hline CETARTIODACTYLA & 0.2006 & 0.3980 & 0.0015 & 0.5781 \\
\hline CHIROPTERA & 0.3469 & 0.1197 & 0.0018 & 0.6055 \\
\hline EULIPOTYPHLA & 0.1907 & 0.1408 & 0.0161 & 0.4169 \\
\hline PRIMATES & 0.2260 & 0.0678 & 0.0004 & 0.7035 \\
\hline RODENTIA & 0.1457 & 0.3009 & 0.0191 & 0.5430 \\
\hline
\end{tabular}



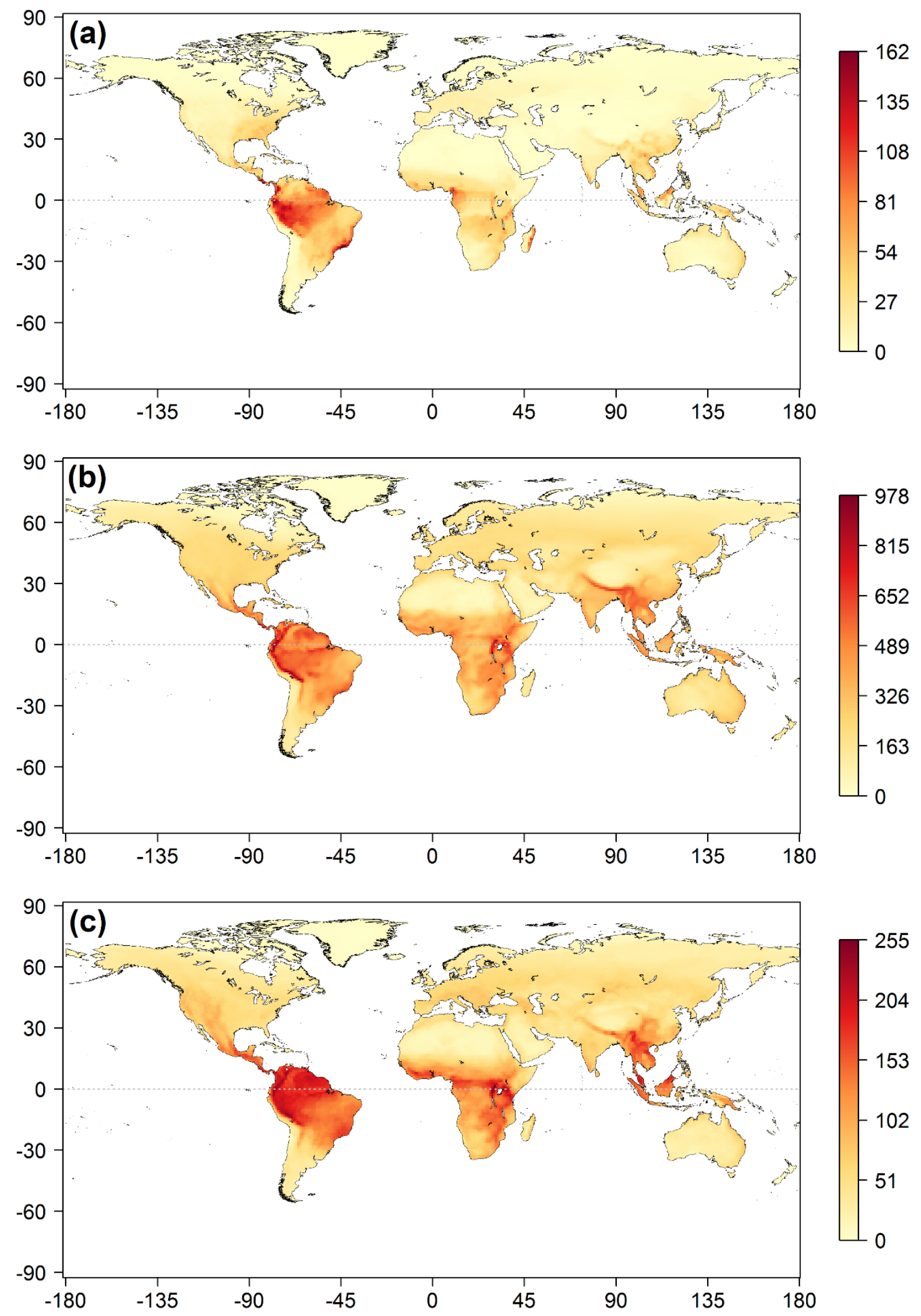

Figure S1. Global (a) amphibian, (b) bird and (c) mammal species richness. A colour scale is used to represent the number of species in squares/pixels with a resolution of $1^{\circ}$. 

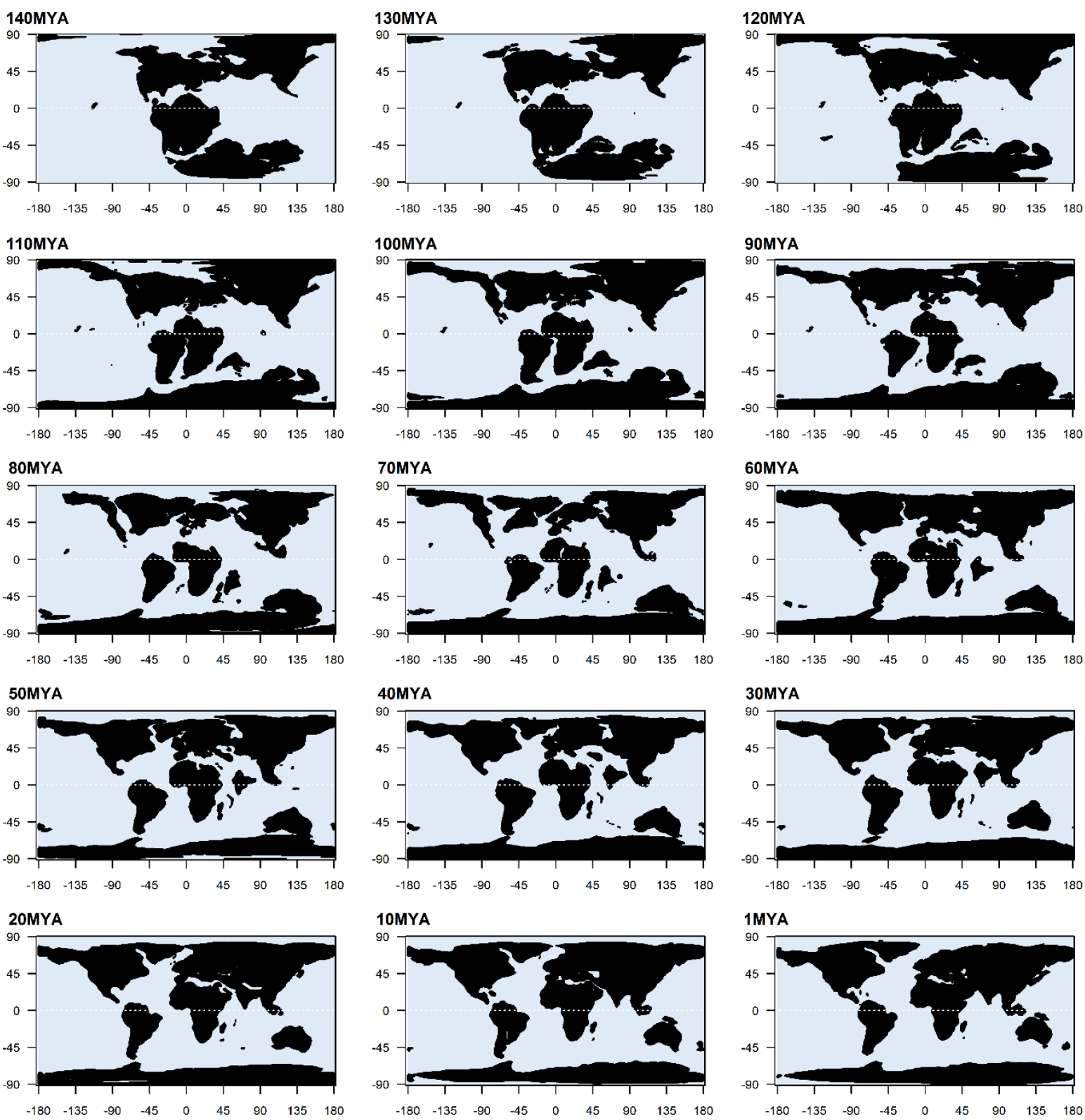

Figure S2. Global plate tectonic reconstructions (Müller et al., 2008) showing the area of exposed continental land surface at each 10 Ma time step (Heine et al., 2015) since the Early Cretaceous (140 Ma). 


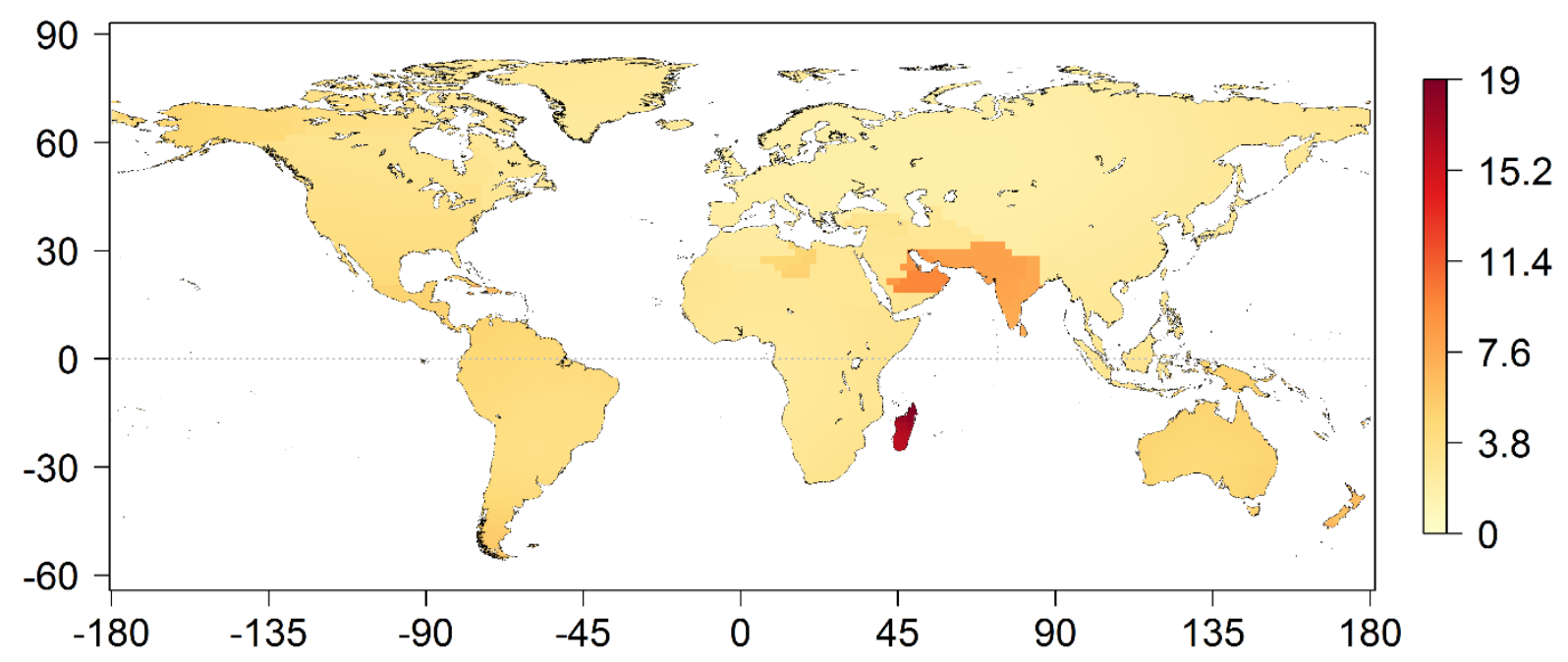

Figure S3. Connectivity through time since the Early Cretaceous ( $140 \mathrm{Ma})$, assessed with plate tectonic reconstructions. Values range from 0 to 19 , where low values indicate higher connectivity to land through time. 

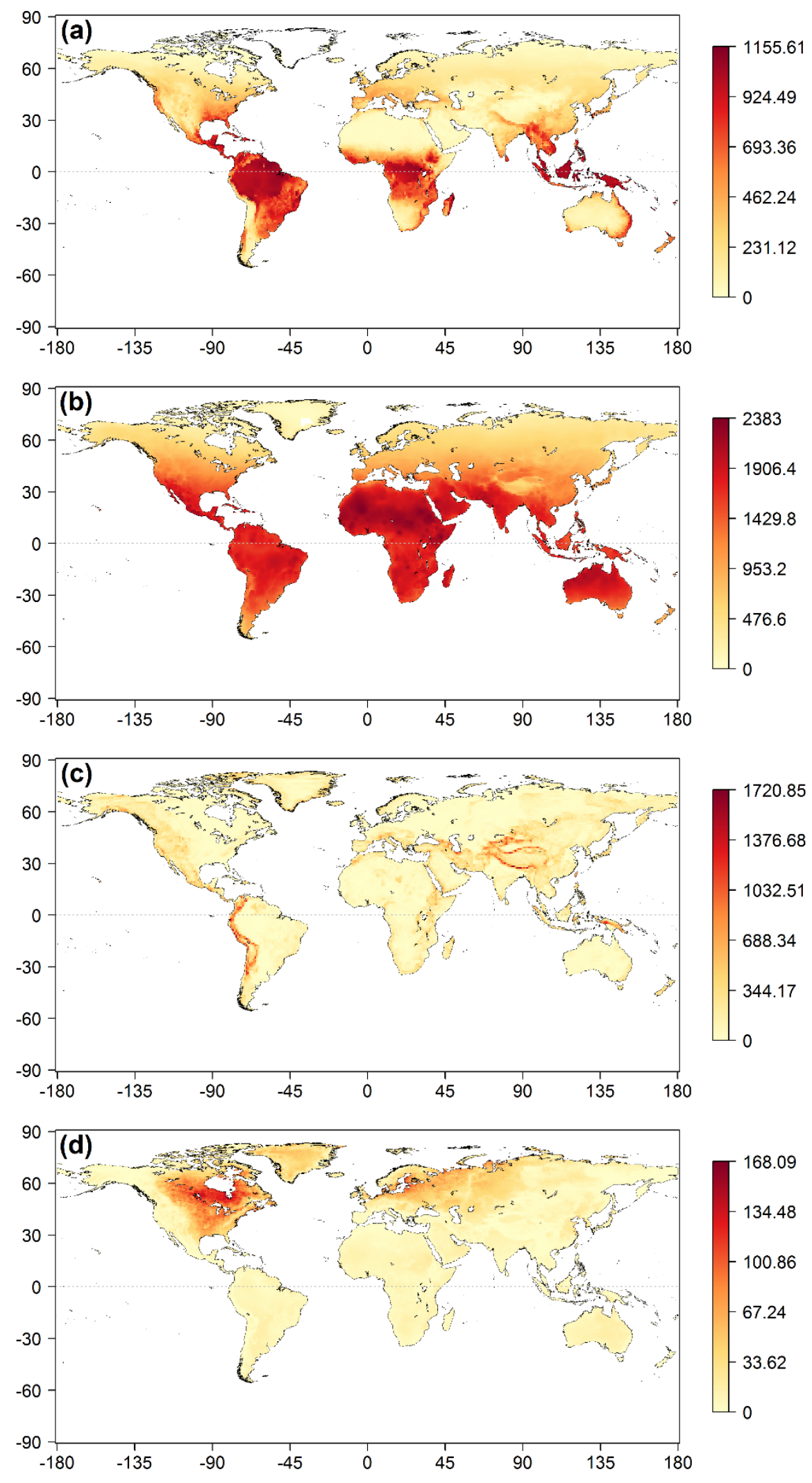

Figure S4. Additional predictor variables used in this study. (a) Net primary productivity [e+09] (NPP; g C/year), (b) potential evapo-transpiration (PET; mm/month), (c) landscape heterogeneity ( $\mathrm{LH}$; standard deviation of elevation values) and (d) Late Quaternary climatechange velocity (CV; $\mathrm{m}$ /year). 


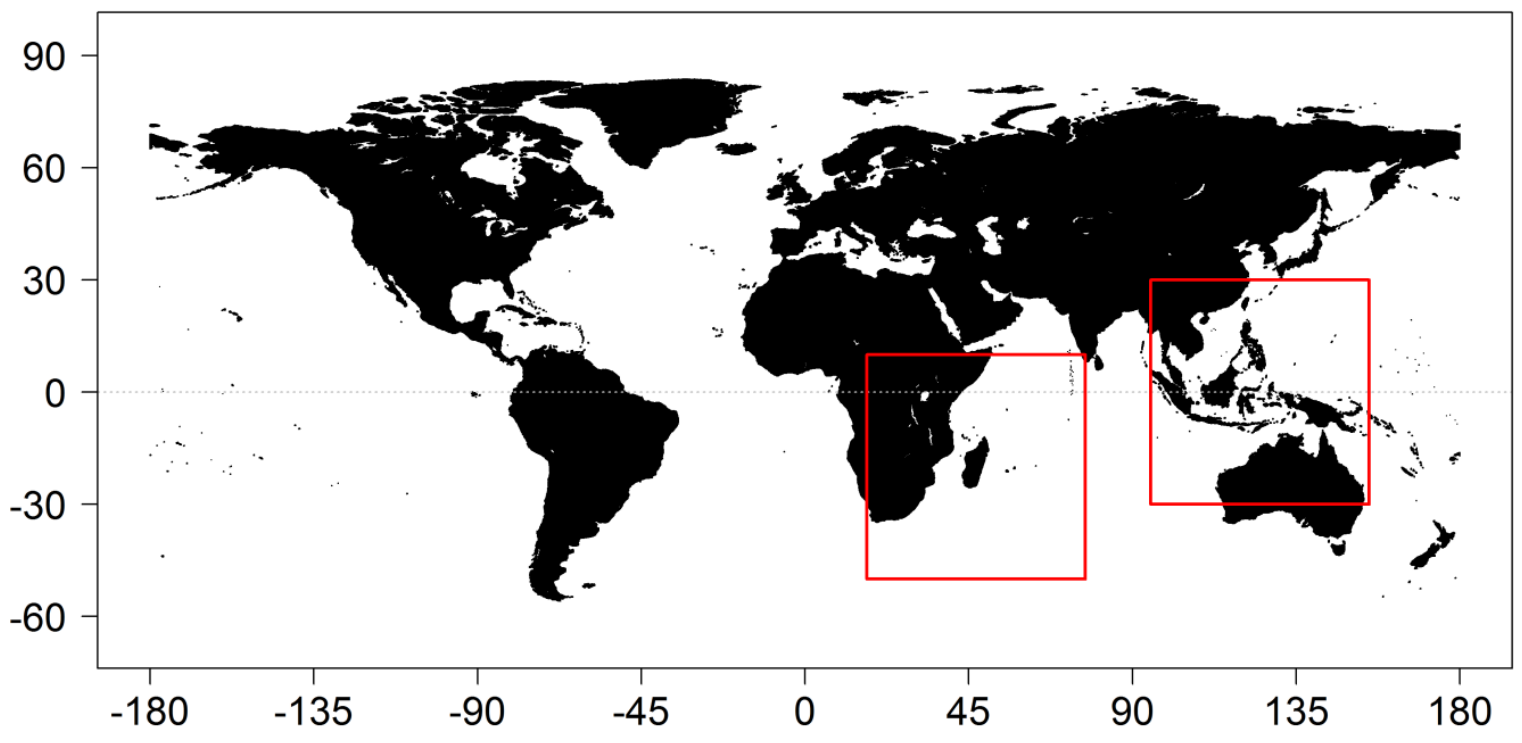

Figure S5. Extent of the two selected regions (i.e. Indo-Australian Archipelago and eastern Africa and Madagascar; $60^{\circ}$ x $60^{\circ}$ squares with red borders) used to relate species richness to historical and contemporary variables (regional models). 


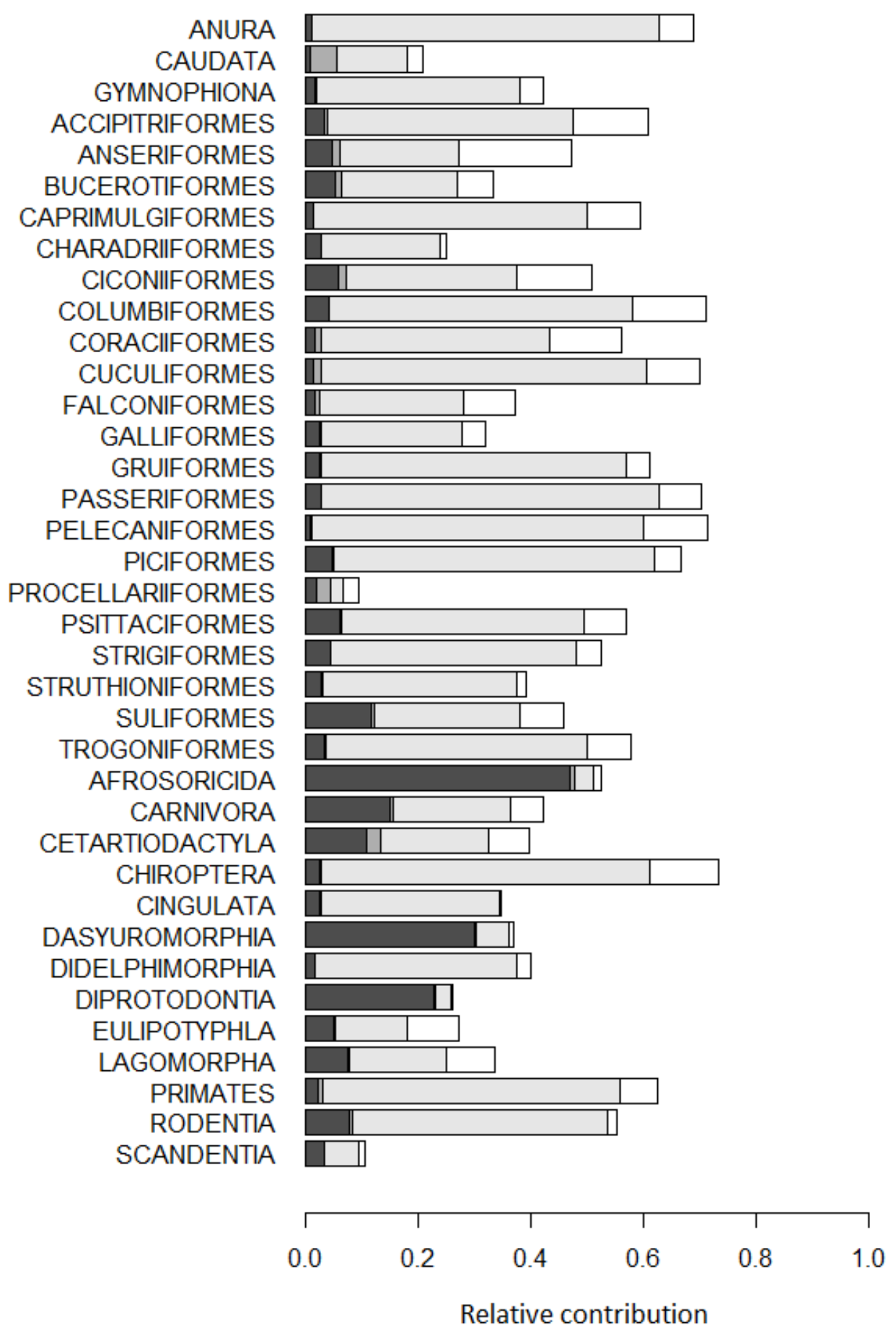

Figure S6. Relative contribution of plate motion history (black; latitudinal shift and land exchanges), Late Quaternary climate-change velocity (dark grey) and contemporary (light grey; net primary productivity, potential evapo-transpiration and landscape heterogeneity) variables in explaining species richness variation at the global level for amphibians, birds and mammals and different taxonomic groups (orders). Values correspond to the independent proportion of explained variance in OLS models (full model including all predictor variables; see Table S2 in Appendix S1). The shared contributions of the variables in the model are shown in white. 


\section{References}

Heine C., Yeo L.G., \& Müller R.D. (2015) Evaluating global paleoshoreline models for the Cretaceous and Cenozoic. Australian Journal of Earth Sciences, 62, 275-287.

Müller R.D., Sdrolias M., Gaina C., Steinberger B., \& Heine C. (2008) Long-term sea-level fluctuations driven by ocean basin dynamics. Science, 319, 1357-1362. 